\title{
Determinants of inward foreign direct investment: Comparison across different country groups ${ }^{* 1}$
}

\author{
Minakshee Das ${ }^{2}$
}

\begin{abstract}
This paper analyses the factors determining inward foreign direct investment, particularly the role of natural endowments and economic and political characteristics of the host country. It expands on the existing literature by focusing on four broad groups of countries: advanced, emerging-market, developing and transition economies, comprising of more than 100 countries in a panel data setting for the period 1996 - 2016. The paper also examines the scenario during the major economic crises - Asian crisis, Dotcom Bubble, Global Financial crisis and Sovereign Debt crisis. The results indicate that the determinants of inward foreign direct investment have changed over time and that the patterns are not uniform across the four country groups. Furthermore, the paper compares the determinants of two major country groups, namely - emerging-market and developing countries by conducting Chow test for equality of coefficients. It is seen that the economic growth and market size has a stronger positive influence on inward FDI flow to emerging-market than to developing economies. Also, emerging-market economies experienced a smaller flow of FDI during Global Financial crisis compared to developing economies. These results have important implications for the policy makers as they can help to identify the regional factors that attract capital inflows.
\end{abstract}

Key words: foreign direct investment, multinational enterprises, determinants, panel data

JEL classification: $F 21, F 23, O 57$

\footnotetext{
* Received: 07-06-2019; accepted: 20-04-2020

1 I would like to acknowledge my supervisor, Dr. Črt Kostevc for his invaluable guidance and Dr. Biswajit Banerjee for his insightful comments and suggestions.

2 PhD candidate, School of Economics and Business, University of Ljubljana, Slovenia. Scientific affiliation: international economics and development economics. Phone: +91 9954703143. E-mail: gargiminakshee22@gmail.com; md1653@student.uni-lj.si.
} 


\section{Introduction}

Foreign direct investment (FDI) is an important aspect of globalization and a dominant component of economic development strategies of both home and host countries. Inward FDI have been rising rapidly since 1990. In the recent years, the emerging-market and developing economies have surpassed advanced economies in receiving capital inflows. This is a manifestation of the increasing receptive attitude towards inward FDI and the consequent changes undertaken by governments to institutions and incentives in order to facilitate these flows. Countries with insufficient domestic savings traditionally relied on foreign aid or foreign debt. But rapid accumulation of external borrowing can result in unsustainable debt dynamics with consequent negative effect on growth performance.

A major reason for the present positive attitude towards FDI is the certainty that these flows benefit both the home and host nations. Moreover, it also assures more stable source of external financing than portfolio investment. FDI flows are essentially non-debt-creating and have other direct and indirect advantages, such as transfer of advanced technology, managerial expertise, creation of job opportunities, spillover effects that involve ancillary supply chains, etc. from the host countries' point of view. These benefits have persuaded the host nations to reduce the barriers of inward FDI. However, these benefits are assessed by the host countries against costs, such as loss of managerial control and risk of losing sovereignty. Some nations still resist the idea of inward FDI and are sceptical about opening up certain sectors due to state security considerations. Taking all these factors into account, it is not surprising that understanding the forces attracting inward FDI is of considerable interest to both economists and policy makers. Not surprisingly, much attention has been given to empirically identifying the important determinants of inward FDI and the implication of the findings for policy formulation and implementation. The bulk of the empirical literature is focused on studies of a single country or a small set of countries.

This paper builds on and extends the existing literature by examining the determinants of FDI inflows over a longer time horizon and with broader country scope. It also contributes to the literature by analysing a wide set of determinants associated with FDI inflows into the four country groupings (advanced, emergingmarket, developing and transition economies). In particular, the main contributions of this paper are that I compare the determinants of FDI inflows for the four broad groups of countries and also examine how the evolution of FDI flows to the different country groups that have been impacted by economic crises. The results indicate that the determinants of inward FDI have changed over time and that the patterns are not uniform across the four country groups. It also supports the general observation that some factors are indeed relevant determinants of inward FDI in almost all countries but to different extents, thereby suggesting that policies 
to attract FDI into those areas should focus improving these country groups' determinants.

The remainder of the paper is organized as follows. Section 2 recalls the literature of theoretical and empirical studies that have examined various factors attracting capital inflows. Section 3 describes the data and the methodology. Section 4 reports the empirical results, and Section 5 concludes.

\section{Literature review}

The literature on determinants of inward FDI is extensive. Some notable surveys of the literature include - Blonigen (2005), Iršová and Havránek (2013), Tang, Yip, and Ozturk (2014), Donnelly (2014), Paul and Singh (2017) and Teixeira, Forte, and Assunção (2017). In this section, the theoretical considerations behind inward FDI are reviewed and the findings of selected recent empirical studies are summarized.

\subsection{Theories of inward FDI}

There are many theories, which explain why multinational enterprises (MNEs) are interested in investing abroad and why they choose one particular country over another for investment. MacDougall (1958) was one of the earliest researchers to analyse FDI flows within the framework of a model that assumed a perfectly competitive market structure. Later, Kemp (1964) proposed a two-country model, and stated that capital moves freely from a capital-abundant country to a capitalscarce country. As a result, the marginal productivity of capital tends to equalize between the two countries.

Hymer (1960) relaxed the assumption of a perfectly competitive market structure and developed a theory based on an imperfect market setting. This approach was subsequently followed by Lemfalussy (1961), Kindleberger (1969), Knickerbocker (1973), Caves (1974), Dunning (1974), and Vaitsos (1976). Hymer used the term "firm-specific" advantage to build his theory. His theory states that firms operating abroad have to confront a number of challenges, the biggest of which is to compete with domestic firms that possess a number of advantages in terms of culture, language, legal system, etc. Also, foreign firms should have some form of market power in order to gain profit from the international investment which compensates these local factors. In the reality of imperfect competition, firms are able to take advantage of their market power to reap profits by investing abroad. Some other researchers also supported this argument. For example, according to Graham \& Krugman (1989), the main reason why European firms invest in the United States is because of technological advantage. 
On the other hand, Robock \& Simmond (1983) claimed that investing abroad is not the only way for firms to exploit firm-specific advantage as firms could manifest their advantages through exporting or licensing. The choice between FDI and licensing/exports is influenced by a host of factors, including local market conditions and size, local government policy, and the riskiness of investment, etc.

Though Hymer's (1960) theory was supported by many researchers, it fails to explain in which locations and when FDI takes place. Later, his theory was extended by Kindleberger (1969) on the basis of monopolistic market framework. Kindleberger claimed that the advantages enjoyed by MNEs could be valuable only when the market is imperfect. He also added that, as long as firms' monopoly profits are high, they are more inclined to invest abroad. Firms with advanced technology prefer to invest in a foreign country instead of sharing it with potential competitors in the foreign market.

Balassa (1966) hypothesized that investors are attracted to economies with large market size as it facilitates cost minimization and specialization of the factors of production. This hypothesis was confirmed in a study by Edward (1991) on FDI flows from $\mathrm{OECD}^{3}$ countries to least developed countries (LDCs). He found that bigger the market size of a country, the larger was its share in the total FDI inflows of the world.

A prerequisite for exploitation of a firm's monopolistic advantages abroad is the support of the host country's policy. It may be that for the purpose of national interest, the host government does not permit free entry of foreign firms into the country. Several hypotheses fall under this imperfect market assumption, of which the location hypothesis and the eclectic theories are the two main models.

According to location hypothesis (first theory), location determinants of FDI play a vital role in attracting good number of funds. For instance, the locational advantage of labour with low wage rates (cheap labour) is an immobile factor of production. But evidence in support of this locational hypothesis is varied. Riedel (1975) found that lower wage rates is one the main factors that determines export-oriented FDI in Taiwan. Furthermore, Saunders (1983), Schneider \& Frey (1985), and Culem (1988) found that a rise in labour cost discouraged capital inflows. In contrast, Hale and $\mathrm{Xu}$ (2016) claimed that a higher wage rate will not deter FDI inflows if the host country has a skilled labour force.

The second theory under the imperfect market assumption was developed by Dunning (1977, 1979 and 1988) that is known as the eclectic theory or the OLI theory. According to Dunning's theory, there are three main groups of determinants of inward FDI, namely: OLI, where O stands for ownership, L stands for location

$\overline{3}$ OECD is Organisation for Economic Cooperation and Development 
and I stand for internalization. Ownership advantage is based on Hymer's firmspecific advantages which address the question of why some firms but not others go abroad, and suggest that a successful MNE has some firm-specific advantages which allow it to overcome the costs of operating in a foreign country. It includes a firm's superiority over its competitors in terms of marketing practices or on the technological front. Location advantages focus on the question of where an MNE chooses to locate. It determines the country-specific advantages, which a firm gain when investing abroad. Finally, internalization advantages influence how a firm chooses to operate autonomously in the foreign country rather than licensing them to another party.

In addition to OLI, there are several other institutional factors which also play an important role in determining inward FDI (Agarwal,1980; Lizondo, 1991 and Moosa, 2002). For instance, political risk, good governance, natural resources, tax policy, trade barriers, etc. Wang and Swain (1995) found that political stability of host nations had a positive impact on FDI. Schneider and Frey (1985) concluded that without considering the governing factors of the host nations the analysis of inward FDI will be incomplete. Furthermore, Campos and Kinoshita (2003) states that a part of inward FDI can be motivated by the availability of natural resources of the host country.

Finally, four main motives of inward FDI are presented in Table 1, which are not only the embodiment of the theories mentioned above, but also the model (Equation (1) in Sub-section 3.2) to be further tested in the later section (Section 4, Empirical results).

\section{Table 1: Main motives of inward FDI}

\begin{tabular}{|l|l|}
\hline \multicolumn{1}{|c|}{ Inward FDI motives } & \multicolumn{1}{c|}{ Description } \\
\hline Market-seeking FDI & $\begin{array}{l}\text { Invest in a host country market in order to be closer to customers and to } \\
\text { serve that market directly rather than through exporting (horizontal FDI). } \\
\text { Market-seeking investors will rate the attractiveness of a host country } \\
\text { mostly with respect to its market size and demand potential. They basically } \\
\text { aim to serve the local and regional markets, by practicing tariff-jumping or } \\
\text { export-substituting. }\end{array}$ \\
\hline Efficiency-seeking FDI & $\begin{array}{l}\text { Enterprises try to exploit economies of specialization and scope across } \\
\text { the value chain, and will slice its production chain by allocating different } \\
\text { prats (or tasks) to countries that allow low-cost production (vertical } \\
\text { fragmentation), particularly where the cost of labor is taken into account. }\end{array}$ \\
\hline Asset-seeking FDI & $\begin{array}{l}\text { Aims to get access to advanced technologies, skills and other highly } \\
\text { developed productive capabilities. Asset-seeking investors value locations } \\
\text { depending on the quality of scientific, technological, and educational } \\
\text { infrastructure they provide and on the availability of a rich pool of highly } \\
\text { skilled labor. }\end{array}$ \\
\hline Resource-seeking FDI & $\begin{array}{l}\text { In order to exploit natural resources or agricultural production in the host } \\
\text { country }\end{array}$ \\
\hline
\end{tabular}




\subsection{Empirical studies of inward FDI}

Since inward FDI helps in promoting growth and employment and facilitating a strong balance of payments position there has been a sharp rise in worldwide FDI since the 1980s (Carp, L., 2012; Inekwe, 2014 and Table 1, Section 1). This development has spawned a rapidly growing literature studying the drivers of inward FDI. As discussed in the previous sub-section (2.1) above, the existing literature is vast and reports a variety of theoretical models and frameworks that attempt to explain inward FDI and the location decision of MNEs.

Empirically, there are three main approaches used so far. Firstly, some studies use micro level data to get a deeper understanding of the factors driving inward FDI decisions of MNEs. In the second approach, bilateral inward FDI flows between countries is examined, inspired by the gravity-type model. And the third approach looks at the aggregate inward FDI flows into a country or a panel of countries. The various approaches reflect the availability of data and the research focus but also reflect the absence of a consensus as to how to model FDI flows.

The specifications in the empirical studies have included a variety of variables to test the hypotheses elaborated in the theoretical literature reviewed in Section 2.1. However, certain variables are common to most of the studies. These include (openness, market growth and potential, natural endowments, etc.). The inclusion of the other variables is guided by data availability and the main objectives of the paper. While most empirical studies included conventional variables, the inclusion of the less conventional ones differs between the various studies depending on the specific focus of the research.

The variables included in the empirical models and the results obtained by 25 recent studies shown in Table 2 (in Appendix).

Variables such as openness and proxies for market size and growth (level of GDP and GDP growth, respectively) are common to virtually all the studies. The results are consistent with a priori expectations and support the hypothesis that inward FDI are positively associated with these variables. However, other macroeconomic variables are more sparsely included in the studies. Among these, of note, is the finding on the real exchange rate (REER) variable. Only 7 out of the 25 studies reviewed in Table 2 include the REER variable, and the results are mixed. In 5 of the studies, the coefficient on the REER is negative but not statistically significant, while in 2 others the coefficient is positive and statistically significant.

However, for some variables like, firing cost, trade and public debt are considered in very few empirical studies. Despite the emphasis placed on the resource-seeking hypothesis, it is found that the natural endowment variable is entered in only 7 out of 25 studies. Out of those 7 studies, 5 appears with the expected positive and 
statistically significant sign in. When the measures of human capital, labour force and research and development were entered in the regression equations, all of them were positively related to FDI inflows.

\section{Methodology}

The variables that are considered in this study are in line with the theoretical considerations behind inward FDI and with the variables that appear in most empirical studies. However, because the data on certain variables are not uniformly available across countries or are not available consistently across time, the list of variables is limited. Due to issues with data availability, this paper had to forego the inclusion of some potentially relevant variables. For instance, labour force with tertiary education, political stability, air transport, etc. While it would have been desirable to include human capital and doing business indicators, but then many observations would have been lost. For example, the inclusion of labour force with tertiary education and doing business results in the number of valid observations falling from 2200 to 450 and 1500 to 222 respectively.

Table 3 describes the list of variables used in the econometric estimation, their source and expected sign.

Table 3: Description of variables

\begin{tabular}{|c|c|c|c|}
\hline Variable & Description & $\begin{array}{c}\text { Ex- } \\
\text { pected } \\
\text { sign } \\
\end{array}$ & Source \\
\hline \multicolumn{4}{|c|}{ Dependent variable } \\
\hline IFDI & Inflow of FDI ( $\%$ of GDP) & & $\begin{array}{l}\text { World Development } \\
\text { Indicator of World Bank }\end{array}$ \\
\hline \multicolumn{4}{|c|}{ Independent variables } \\
\hline OPEN & Trade openness index $=($ exports + imports $) /$ GDP & + & \begin{tabular}{|l|} 
World Development \\
Indicator of World Bank
\end{tabular} \\
\hline $\mathrm{GDPG}_{(\mathrm{t}-1)}$ & GDP per capita growth (annual \%) lagged by 1 year & $+/-$ & $\begin{array}{l}\text { World Development } \\
\text { Indicator of World Bank }\end{array}$ \\
\hline GDPP & GDP, PPP (constant 2011 international \$) & + & $\begin{array}{l}\text { World Development } \\
\text { Indicator of World Bank }\end{array}$ \\
\hline $\operatorname{REER}_{(\mathrm{t}-1)}$ & $\begin{array}{l}\text { Real Effective Exchange Rate index }(2010=100) \\
\text { lagged by } 1 \text { year. }\end{array}$ & $+/-(?)$ & $\begin{array}{l}\text { International Monetary } \\
\text { Fund }\end{array}$ \\
\hline GFCF & Gross fixed capital formation ( $\%$ of GDP) & + & \begin{tabular}{|l|} 
World Development \\
Indicator of World Bank
\end{tabular} \\
\hline ORES & Ores and metals exports (\% of merchandise exports) & + & \begin{tabular}{|l|} 
World Development \\
Indicator of World Bank \\
\end{tabular} \\
\hline INFRA & Fixed telephone subscription (per 100 person) & + & $\begin{array}{l}\text { World Development } \\
\text { Indicator of World Bank }\end{array}$ \\
\hline
\end{tabular}




\begin{tabular}{|l|l|c|l|}
\hline Variable & \multicolumn{1}{|c|}{ Description } & $\begin{array}{c}\text { Ex- } \\
\text { pected } \\
\text { sign }\end{array}$ & Source \\
\hline GOV & $\begin{array}{l}\text { Control of Corruption captures perceptions of the extent } \\
\text { to which public power is exercised for private gain, } \\
\text { including both petty and grand forms of corruption, } \\
\text { as well as "capture" of the state by elites and private } \\
\text { interests. Estimate gives the country's score on the } \\
\text { aggregate indicator, in units of a standard normal } \\
\text { distribution, i.e. ranging from approximately -2.5 to 2.5. }\end{array}$ & $+/-$ & $\begin{array}{l}\text { World Governance } \\
\text { Indicator of World Bank }\end{array}$ \\
\hline
\end{tabular}

Source: Authors' compilation

The descriptive statistics and correlation matrix is presented in the Appendix (Table A1 and Tables A2 respectively). The sample is grouped into 4 different country groups (listed in Appendix Table A3), namely - advanced, emergingmarket, developing and transition economies. The country groupings follow the classification by UNCTAD. However, UNCTAD's classification includes many emerging-market economies simultaneously as developing economies. These cases of emerging-market economies have been removed from the developing country group.

\subsection{Econometric specification}

Several regression equations are estimated for the entire sample and for each country group. The basic specification consistent with theory and hypotheses espoused in literature is shown below.

$$
\begin{aligned}
& I F D I=\alpha+\beta_{1} \text { OPEN }+\beta_{2} G D P G_{(t-1)}+\beta_{3} G D P P+\beta_{4} R E E R_{(t-1)}+ \\
& +\beta_{4} G F C F+\beta_{5} \text { ORES }+\beta_{5} I N F R A+\beta_{6} G O V+\mu
\end{aligned}
$$

Subsequently the analysis add to the basic specification in two important ways. It includes dummies for the four country groups and time dummies for crises periods. Then, estimate several regression equations for the entire sample, each country group and then examine if there is significant difference in the coefficients on the explanatory variables between different country groups, particularly between emerging-market and developing economies by considering the dummies representing the major economic crises.

The regression equations are estimated by the Ordinary Least Square (OLS) method, as has been done by 21 out of 25 studies reviewed earlier in Table 2 . The remaining 4 studies used empirical methodologies like- 2SLS (wo-stage least square), ADRL (autoregressive distributed lag), Extreme Bound Analysis and Tobit for analysing the determinants of FDI. Moreover, as a means of robustness 
check this paper includes time fixed-effects (FE) in the main regressions, including the dummies representing economic crises. Additionally, to deal endogeneity problem and to allow for the possibility of causation, this paper applies system generalized method of moments (GMM) as proposed by Arellano \& Bover (1995) and Blundell-Bond (1998) building on Arellano-Bond (1991). This is also done to check for possible dynamic effects in the regressions, i.e. to see whether inward FDI is correlated with past observations. Compared to the baseline regression, this means adding the lagged dependent variable on the righthand side.

\section{Empirical data and analysis}

This section presents the empirical results, where the first section (4.1) gives an overall view of the determinants of FDI inflows for the entire sample. The second section (4.2) reports the determinants of FDI inflows by the major country groups, followed by a comparison of the determinants of FDI inflows between emergingmarket and developing economies in section 4.3. The last section (4.4) does a robustness check of main results with other empirical methods.

\subsection{Determinants of inward FDI for the entire sample}

Table 4 shows the determinants of inward FDI for the entire sample of countries that includes - advanced, emerging-market, developing and transition economies. The specification includes the standard macroeconomic variables discussed in the literature survey and four time dummies representing the economic crises periods (Asian crisis, Dotcom Bubble, Global Financial crisis and Sovereign Debt crisis), in order to allow for variations in the dynamics of FDI inflows over time.

Table 4, column 1 shows that inward FDI are positively related to OPEN, ORES (natural resource intensity) and INFRA. These findings are in line with expectations and with the findings of the existing literature. However, contrary to expectations, coefficients on $\mathrm{GDPG}_{(\mathrm{t}-1)}$ i.e. lagged GDP growth, GDPP (the market size variable) and the $\operatorname{REER}_{(\mathrm{t}-1)}$ i.e. lagged REER are not statistically significant. 
Table 4: Determinants of inward FDI for entire sample Dependent variable: IFDI (the ratio of IFDI flow to GDP)

\begin{tabular}{|c|c|c|}
\hline & 1 & 2 \\
\hline & Full-sample $^{1}$ & Full-sample ${ }^{2}$ \\
\hline \multirow{2}{*}{ OPEN } & $0.0942 * * *$ & $0.0963 * * *$ \\
\hline & $(0.0161)$ & $(0.0172)$ \\
\hline \multirow{2}{*}{$\operatorname{GDPG}_{(t-1)}$} & -0.0158 & -0.0224 \\
\hline & (0.0544) & $(0.0554)$ \\
\hline \multirow[b]{2}{*}{ GDPP } & $1.29 \mathrm{e}^{-7}$ & $1.03 \mathrm{e}^{-7}$ \\
\hline & $\left(2.62 \mathrm{e}^{-7}\right)$ & $\left(2.60 \mathrm{e}^{-7}\right)$ \\
\hline \multirow{2}{*}{$\operatorname{REER}_{(t-1)}$} & 0.00017 & 0.000175 \\
\hline & $(0.00022)$ & $(0.000215)$ \\
\hline \multirow{2}{*}{ GFCF } & 0.0551 & 0.0599 \\
\hline & $(0.0433)$ & $(0.0401)$ \\
\hline \multirow{2}{*}{ ORES } & $0.0508 * * *$ & $0.0494 * * *$ \\
\hline & $(0.00959)$ & $(0.00983)$ \\
\hline \multirow{2}{*}{ INFRA } & $0.0772 * * *$ & $0.0457^{* *}$ \\
\hline & $(0.0248)$ & $(0.0205)$ \\
\hline \multirow{2}{*}{ GOV } & -0.37 & -0.53 \\
\hline & $(0.342)$ & (0.396) \\
\hline \multicolumn{3}{|l|}{\begin{tabular}{|l} 
Country groups \\
\end{tabular}} \\
\hline \multirow{2}{*}{ Advanced } & & 0.967 \\
\hline & & (1.138) \\
\hline \multirow{2}{*}{ Emerging-market } & & $-2.264 * * *$ \\
\hline & & $(0.681)$ \\
\hline \multirow{2}{*}{ Developing } & & $-1.161 *$ \\
\hline & & $(0.691)$ \\
\hline \multicolumn{3}{|l|}{ Economic crisis } \\
\hline \multirow{2}{*}{$\begin{array}{l}\text { Asian crisis } \\
(1997-1998)\end{array}$} & -0.576 & -0.569 \\
\hline & $(0.421)$ & $(0.425)$ \\
\hline \multirow{2}{*}{$\begin{array}{l}\text { Dotcom Bubble } \\
(2001)\end{array}$} & $-0.916^{*}$ & $-0.831^{*}$ \\
\hline & $(0.487)$ & $(0.475)$ \\
\hline \multirow{2}{*}{$\begin{array}{l}\text { Global Financial crisis } \\
(2007-2008)\end{array}$} & $3.017^{*}$ & $3.042 *$ \\
\hline & $(1.718)$ & $(1.72)$ \\
\hline \multirow{2}{*}{$\begin{array}{l}\text { Sovereign Debt crisis } \\
(2011-2012)\end{array}$} & 1.121 & 1.078 \\
\hline & (1.125) & (1.111) \\
\hline \multirow{2}{*}{ Constant } & $-6.739 * * *$ & $-5.525 * * *$ \\
\hline & $(1.514)$ & $(1.508)$ \\
\hline Observations & 2,669 & 2,669 \\
\hline R-squared & 0.121 & 0.124 \\
\hline \multirow{2}{*}{ F-ratio } & 30.53 & 25.04 \\
\hline & $(0.000)$ & $(0.000)$ \\
\hline
\end{tabular}

${ }^{1}$ Full-sample without any country group dummy; ${ }^{2}$ Full-sample with omitted country group as the transition economies; Figures in parentheses are robust standard errors.; $* * *, * * *$ are significant respectively to $\mathrm{p}<0.01, \mathrm{p}<0.05, \mathrm{p}<0.1 ; \mathrm{e}=10$ 
These results have to be treated with a degree of caution because the responsiveness of inward FDI flows are likely to be different for different groups of countries. So, the estimates of consolidated sample, might not be representative for country heterogeneity. Therefore, in an alternative specification, dummies for advanced, emerging-market and developing countries (considering transition economies as the omitted category) are included. Results show that the coefficients on emergingmarket and developing economies are negative and statistically significant (see Table 4, column 2), suggesting that other things remaining the same, inward FDI flows are smaller to these countries groups relative to advanced and transition economies. The coefficient on the emerging-market dummy is more negative than the coefficient on developing economies indicating relatively weaker inflows to emerging-market economies compared to developing economies.

Now looking at the economic crises, there was a negative inflow of FDI during the Dotcom Bubble (2001) crisis while in case of Global Financial crisis (2007-2008) it experienced an increase in capital inflows.

\subsection{Investigating the determinants of inward FDI by major country groups}

Now as the determinants of FDI inflows by major country groups (see Table 5) are looked upon, the results are more profound. It is clear that OPEN is positively significant for advanced, emerging-market and developing economies as these country groups might have adopted policies that favour foreign trade, encouraging domestic producers to export, increasing their profitability and attracting foreign investors. Additionally, the market-growth (GDPG) has a positive impact on emerging-market and transition economies, which is in line with many previous studies (Kinda, 2010; Carp, L., 2012 and Kumari \& Sharma, 2017). These economies offer more opportunities for higher profits to the foreign investors as they are at their growing stage. Surprisingly, the market-size determinant (GDPP) is negatively related to developing economics but positively significant in case of advanced economies. In support of the negative relation between GDPP and developing economies, Holland \& Pain (1998) and Asiedu (2002) too found that market-size as insignificant determinants of FDI inflows. Again, the developing economies has a negative significant relationship between inward FDI and real exchange rate (REER) indicating that it receives smaller amount of FDI with a more appreciated lagged exchange rate. In this situation, the investors choose to produce domestically rather than investing abroad. In contrast, the REER have a positive impact on transition economies which states that as the currency depreciates, the purchasing power of the investors in foreign currency terms is enhanced, increasing the inflow of FDI to the transition economies. The negative and insignificant effect of GFCF makes it clear that the privatization and ownership changes do not affect GFCF of emerging-market economies which is in line with the findings of Lipsey (2000) and Krkoska (2001). On the other hand, the GFCF of developing and transition economies has a positive impact on FDI inflows. 
It is also evident that FDI inflows of emerging-market and developing economies is largely driven by natural resources (ORES). In short, my results are consistent with the resource-seeking strategy (Dunning \& Lundan, 2008). With respect to infrastructure, fixed telephone subscription per 100 inhabitants helps to build up the confidence of foreign investors and increase FDI inflows for three main country groups- advanced, emerging-market and developing economies which is similar to the findings of several extant studies (Asiedu, 2006 and Xaypanya et al., 2015).

Table 5: Determinants of inward FDI by major country groups Dependent variable: IFDI (the ratio of IFDI flow to GDP)

\begin{tabular}{|c|c|c|c|c|}
\hline & 1 & 2 & 3 & 4 \\
\hline & Advanced & Emerging-market & Developing & Transition \\
\hline \multirow{2}{*}{ OPEN } & $0.213 * * *$ & $0.0386^{* * * *}$ & $0.0546^{* * * *}$ & 0.00673 \\
\hline & $(0.0558)$ & $(0.00479)$ & $(0.00599)$ & $(0.017)$ \\
\hline \multirow{2}{*}{$\mathrm{GDPG}_{(\mathrm{t}-1)}$} & -0.402 & $0.126^{* * *}$ & 0.0215 & $0.129 *$ \\
\hline & $(0.306)$ & $(0.0377)$ & $(0.0325)$ & $(0.0661)$ \\
\hline \multirow{2}{*}{ GDPP } & $4.91 \mathrm{e}^{-13 * *}$ & $8.86 \mathrm{e}^{-14}$ & $-2.43 \mathrm{e}^{-12 * * *}$ & $-3.17 \mathrm{e}^{-13}$ \\
\hline & $\left(2.28 \mathrm{e}^{-13}\right)$ & $\left(7.14 \mathrm{e}^{-14}\right)$ & $\left(9.08 \mathrm{e}^{-13}\right)$ & $\left(4.70 \mathrm{e}^{-13}\right)$ \\
\hline \multirow{2}{*}{$\operatorname{REER}_{(\mathrm{t}-1)}$} & 0.000429 & -0.000132 & $-0.000140^{*}$ & $0.000375^{* *}$ \\
\hline & $(0.000615)$ & $(0.000128)$ & $\left(7.99 \mathrm{e}^{-5}\right)$ & $(0.000188)$ \\
\hline \multirow{2}{*}{ GFCF } & 0.049 & -0.0393 & $0.138 * * *$ & $0.436 * * *$ \\
\hline & $(0.192)$ & $(0.0321)$ & $(0.0303)$ & $(0.144)$ \\
\hline \multirow{2}{*}{ ORES } & -0.0304 & $0.0866^{* * *}$ & $0.0445^{* * *}$ & -0.0343 \\
\hline & $(0.135)$ & $(0.0163)$ & $(0.0094)$ & $(0.0311)$ \\
\hline \multirow{2}{*}{ INFRA } & $0.218 * *$ & $0.0494 * * *$ & $0.0953 * * *$ & $-0.146 * * *$ \\
\hline & $(0.0909)$ & $(0.0134)$ & $(0.018)$ & $(0.0494)$ \\
\hline \multirow{2}{*}{ GOV } & -0.354 & -0.00962 & -0.227 & -0.717 \\
\hline & $(0.928)$ & $(0.206)$ & $(0.291)$ & $(0.708)$ \\
\hline \multicolumn{5}{|l|}{ Economic crisis } \\
\hline \multirow{2}{*}{$\begin{array}{l}\text { Asian crisis } \\
(1997-1998)\end{array}$} & -0.00242 & 0.25 & -0.463 & -0.682 \\
\hline & $(1.52)$ & $(0.342)$ & $(0.421)$ & $(1.374)$ \\
\hline \multirow{2}{*}{$\begin{array}{l}\text { Dotcom Bubble } \\
\text { (2001) }\end{array}$} & -0.364 & -0.306 & -0.619 & -0.796 \\
\hline & $(1.642)$ & $(0.535)$ & $(0.457)$ & $(1.745)$ \\
\hline \multirow{2}{*}{$\begin{array}{l}\text { Global Financial crisis } \\
(2007-2008)\end{array}$} & 8.717 & $2.010 * *$ & $1.888 * * *$ & 0.657 \\
\hline & $(6.669)$ & $(1.016)$ & $(0.492)$ & $(1.394)$ \\
\hline \multirow{2}{*}{$\begin{array}{l}\text { Sovereign Debt crisis } \\
(2011-2012)\end{array}$} & 2.358 & $-0.650^{*}$ & $1.066^{*}$ & 0.649 \\
\hline & $(3.545)$ & $(0.333)$ & $(0.585)$ & $(0.75)$ \\
\hline \multirow{2}{*}{ Constant } & $-24.24 * *$ & -0.43 & $-4.292 * * *$ & -3.828 \\
\hline & (9.89) & $(0.621)$ & $(0.814)$ & $(3.868)$ \\
\hline Observations & 697 & 648 & 1,234 & 231 \\
\hline R-squared & 0.16 & 0.364 & 0.419 & 0.34 \\
\hline F-ratio & & & & \\
\hline
\end{tabular}

Figures in parentheses are robust standard errors.; ***, **, * are significant respectively to $\mathrm{p}<0.01, \mathrm{p}<0.05, \mathrm{p}<0.1 ; \mathrm{e}=10$ 
Global financial crisis (2007-2008) which originated in the advanced economies and caused a pronounced slowdown in the global economy had a positive significant impact on emerging- market and developing economies. In other words, during the crisis both these country groups attracted FDI inflows. There might be two main reasons behind this attractiveness to investors. First, due to large exchange rate depreciation the domestic production costs of foreign firms is reduced making the crisis-affected region more attractive for export-oriented investment. Second, the sudden fall of asset prices offer attractive buying opportunities to the foreign investors. In case of the Sovereign Debt crisis (2011-2012), which started in the Eurozone and later intensified by the Greek crisis affected the emerging-market economies the most. Emerging-market and developing economies were statistically significant throughout that period where OPEN, ORES and INFRA were the main determinants in attracting capital inflows. However, the inward FDI of emergingmarket economies were negative during that crisis period. The developing economies attracted foreign investors may be due to their liberal regime (due to crisis and falling of asset prices), encouraging "fire-sale" FDI (leading to mergers and acquisitions).

\subsection{Comparison of determinants of inward FDI between emerging-market and developing economies}

Now when the estimates for emerging-market and developing economies (Table 6 , column 1) are looked, it is found that inward FDI flows are more attracted to open (OPEN) economies with huge stock of physical assets (GFCF), good telecommunication service (INFRA) and natural resources (ORES). However, level of GDP which is traditionally proxy for market size appear with an unexpected negative sign, but statistically significant at $10 \%$ level. But the size of the coefficient suggest that the impact is small. This finding could be interpreted that FDI flows go to destinations with less growth and lower level of GDP because the returns may be higher. Also, a negative significant relationship between inward FDI and real exchange rate (REER) is found, indicating that inward FDI are smaller in countries with a more appreciated lagged exchange rate. Feenstra (1998) also obtained a similar result and noted that this could be suggestive that host country appreciation reduces the wealth of foreign investors and will reduce investments. In addition, inward FDI which are governed by locational advantages that serves as a springboard for markets for exports to developing countries will be deterred by exchange rate appreciation in the host country because it makes exports more expensive.

It is of interest to determine whether there is a significant difference in the coefficients on the other explanatory variables between emerging-market and developing economies. It is performed in two alternative ways. First, the test for the equality of all the coefficients for emerging-market and developing 
economies by conducting Chow test for equality of coefficients (this is the test of homogeneity of the FDI equations for emerging-market and developing countries). The second method, estimates a regression equation for the combined sample of emerging-market and developing countries with the same explanatory variables but with the addition of a set of intercept and slope dummy variables representing the products of each of the independent variables and the dummy variable for emerging-market economies. In this specification, the focus is on the interaction terms to determine which of the particular variables are different between the two country groups.

For the Chow test the computed F-ratio is given by:

$$
\frac{\left\{\mathrm{RSS}_{\mathrm{EMER}+\mathrm{DEVG}}-\left(\mathrm{RSS}_{\mathrm{EMER}}+\mathrm{RSS}_{\mathrm{DEVG}}\right)\right\} / \mathrm{K}}{\left(\mathrm{RSS}_{\mathrm{EMER}}+\mathrm{RSS}_{\mathrm{DEVG}}\right) /\left(\mathrm{N}_{\mathrm{EMER}}+\mathrm{N}_{\mathrm{DEVG}}-2 \mathrm{~K}\right)}
$$

where, $\mathrm{K}$ is the number of independent variables including the constant term, $\mathrm{N}$ is the number of observations and RSS is the residual sum of squares.

The Chow test yields an F-ratio of 10.353 (critical value: $F_{0.01}=2.77$ ): the FDI equation for the two country groups are significantly different at the $1 \%$ level.

When the equation with interaction terms (see Table 6, column 4) is observed, it is found that the coefficients on corruption index (GOV) for emergingmarket economies are not significantly different from comparable coefficients for developing country group. The coefficients on openness (OPEN), GFCF, natural endowments ORES and the time dummy representing Global Financial crisis (2007-2008) for emerging-market economies are statistically significant and negative compared to those for developing economies. In other words, for a given degree of openness, inward FDI is lower for emerging-market economies compared to developing countries, GFCF and ORES matters less for inward FDI flows to emerging-market economies compared to developing economies and other things remaining the same, emerging-market economies experienced a smaller flow of FDI during Global Financial crisis compared to developing economies. 
Minakshee Das $\bullet$ Determinants of inward foreign direct investment...

Table 6: Contrasting determinants of inward FDI for emerging-market and developing economies

Dependent variable: IFDI (the ratio of IFDI flow to GDP)

\begin{tabular}{|c|c|c|c|c|}
\hline & 1 & 2 & 3 & 4 \\
\hline & $\begin{array}{c}\text { Emerging-market } \\
\& \text { developing }\end{array}$ & $\begin{array}{c}\text { Emerging- } \\
\text { market }\end{array}$ & Developing & $\begin{array}{l}\text { Interaction with } \\
\text { emerging-market }\end{array}$ \\
\hline \multirow{2}{*}{ OPEN } & $0.0458 * * *$ & $0.0386^{* * *}$ & $0.0546^{* * *}$ & $-0.0160 * * *$ \\
\hline & $(0.00231)$ & $(0.00305)$ & $(0.00339)$ & $(0.00479)$ \\
\hline \multirow{2}{*}{$\mathrm{GDPG}_{(\mathrm{t}-1)}$} & 0.043 & $0.126^{* * *}$ & 0.0215 & $0.104 *$ \\
\hline & $(0.0279)$ & $(0.04)$ & $(0.0361)$ & $(0.0579)$ \\
\hline \multirow{2}{*}{ GDPP } & $-3.04 \mathrm{e}^{-13 * * *}$ & $8.86 \mathrm{e}^{-14}$ & $-2.43 \mathrm{e}^{-12 * *}$ & $2.53 \mathrm{e}^{12 * * *}$ \\
\hline & $\left(9.20 \mathrm{e}^{-14}\right)$ & $\left(9.87 \mathrm{e}^{-14}\right)$ & $\left(9.98 \mathrm{e}^{-13}\right)$ & $\left(9.40 \mathrm{e}^{-13}\right)$ \\
\hline \multirow{2}{*}{$\operatorname{REER}_{(t-1)}$} & $-0.000158^{* *}$ & -0.000132 & $-0.000140 *$ & $7.93 \mathrm{e}^{-6}$ \\
\hline & $\left(6.64 \mathrm{e}^{-5}\right)$ & $(0.000103)$ & $\left(8.30 \mathrm{e}^{-5}\right)$ & $(0.000144)$ \\
\hline \multirow{2}{*}{ GFCF } & $0.122 * * *$ & -0.0393 & $0.138 * * *$ & $-0.178 * * *$ \\
\hline & $(0.0154)$ & $(0.0329)$ & $(0.0178)$ & $(0.0422)$ \\
\hline \multirow{2}{*}{ ORES } & $0.0638^{* * *}$ & $0.0494 * * *$ & $0.0953 * * *$ & $-0.0460 *$ \\
\hline & $(0.0111)$ & $(0.0149)$ & $(0.0176)$ & $(0.024)$ \\
\hline \multirow{2}{*}{ INFRA } & $0.0560 * * *$ & $0.0866^{* * *}$ & $0.0445^{* * *}$ & $0.0421 * *$ \\
\hline & $(0.00715)$ & $(0.0129)$ & $(0.00857)$ & $(0.0172)$ \\
\hline \multirow{2}{*}{ GOV } & -0.0576 & -0.00962 & -0.227 & 0.218 \\
\hline & $(0.183)$ & $(0.239)$ & $(0.272)$ & $(0.379)$ \\
\hline \multicolumn{5}{|l|}{ Economic crisis } \\
\hline \multirow{2}{*}{$\begin{array}{l}\text { Asian crisis } \\
(1997-1998)\end{array}$} & -0.369 & 0.25 & -0.463 & 0.774 \\
\hline & $(0.381)$ & $(0.524)$ & $(0.5)$ & $(0.313)$ \\
\hline \multirow{2}{*}{$\begin{array}{l}\text { Dotcom Bubble } \\
(2001)\end{array}$} & -0.413 & -0.306 & -0.619 & 0.982 \\
\hline & $(0.475)$ & $(0.681)$ & $(0.607)$ & $(0.123)$ \\
\hline \multirow{2}{*}{$\begin{array}{l}\text { Global Financial crisis } \\
(2007-2008)\end{array}$} & $1.941 * * *$ & $2.010 * * *$ & $1.888 * * *$ & $-1.717 * *$ \\
\hline & $(0.357)$ & $(0.509)$ & $(0.455)$ & $(0.735)$ \\
\hline \multirow{2}{*}{$\begin{array}{l}\text { Sovereign Debt crisis } \\
(2011-2012)\end{array}$} & 0.542 & -0.65 & $1.066^{* *}$ & 0.749 \\
\hline & $(0.359)$ & $(0.522)$ & $(0.457)$ & $(0.427)$ \\
\hline \multirow{2}{*}{ Constant } & $-3.390 * * *$ & -0.43 & $-4.292 * * *$ & $-4.292 * * *$ \\
\hline & $(0.461)$ & $(0.786)$ & $(0.571)$ & $(0.534)$ \\
\hline Observations & 1,882 & 648 & 1,234 & 1,882 \\
\hline R-squared & 0.37 & 0.364 & 0.419 & 0.41 \\
\hline \multirow{2}{*}{ F-ratio } & 91.66 & 30.25 & 73.32 & 51.61 \\
\hline & $(0.000)$ & $(0.000)$ & $(0.000)$ & $(0.000)$ \\
\hline RSS & 39161.5822 & 9051.85674 & 27646.3892 & 36697.4059 \\
\hline
\end{tabular}

Figures in parentheses are standard errors.; ***, **,* are significant respectively to $\mathrm{p}<0.01$, $\mathrm{p}<0.05, \mathrm{p}<0.1 ; \mathrm{e}=10$ 
In contrast, the regression result indicates the economic growth (GDPG) and market size (GDPP) have a stronger positive influence on inward FDI flow to emergingmarket than to developing economies.

\subsection{Robustness checks}

Later on, FE and system GMM estimations are performed as a robustness check which also adds to the existing literature. For the system GMM to be valid, it is essential that its preconditions are met, as otherwise instrumental variable (IV) regression is actually preferable. With a view to testing whether GMM is actually more desirable then IV, this paper will need to see whether estimating a dynamic model is justified (i.e. is the lagged dependent variable significant) and whether heteroskedasticity is present. In this case, the GMM estimator is more efficient than the simple IV estimator. By contrast, if heteroskedasticity is not present, the GMM estimator is no worse asymptotically than the IV estimator. In case of homoscedasticity and if the lagged dependent variable is not significant then, simple IV regressions is used. However, for this approach, this paper will need to ensure that two assumptions are satisfied. First, relevant instruments would need to be distributed independently of the error process, and second, they would need to be sufficiently correlated with the included endogenous regressors.

The robustness check results are reported in Appendix B which validates the baseline findings.

\section{Results and discussion}

The results are in line with earlier studies of the literature. Inflows are positively influenced by openness, market growth and potential and are also attracted to destinations that are resource-rich having adequate infrastructure. In addition, the likelihood of inward FDI flows increases for countries with the depreciation of the real exchange rate.

Within this pattern of results that apply qualitatively for all country groups, it is observed that the sensitivity of inward FDI flows by various variables are different for advanced, emerging-market, developing and transition economies. Notably, the openness factor is stronger for developing than for emerging-market economies. Whereas, growth and potential of GDP are more significant for emerging-market economies. It is also notable that the sensitivity of inflows to quality of governance is not significantly different between emerging-market and developing economies. The results confirm the increasing importance of good INFRA for inward FDI flows to advanced economies whereas for emerging-market and developing economies the importance of this variable was strongest during the period of Global Financial crisis (2007-2008). 
Such results highlight the prominence of governmental actions over improving the investment environment, in particular the importance of investing in infrastructure, improving the quality of institutions (by controlling corruption and enforcing contracts and property rights), and promoting policies to open/ liberalise the economy (by adopting export-oriented policies and eliminating/lowering taxes on corporate profits).

\section{Conclusion}

FDI flows have increased manifold in the last two decades. Increasingly these flows have shifted towards emerging-market and developing economies. In view of the potential beneficial effects of FDI for both the home and host countries, researchers have devoted considerable attention in analysing the determinants of inward FDI flows.

This paper sheds light on the determinants of inward FDI flows across a very large group of countries - advanced, emerging-market, developing and transition economies over a time period that spans the Asian crisis, Dotcom Bubble, Global Financial crisis and Sovereign Debt crisis. The focus is on the traditional variables such as- openness, market growth and size, competitiveness, capital and resource endowments, physical infrastructure and governance. However, lack of data on certain variables uniformly across countries have precluded from inclusion of wider range of explanatory variables.

The results of the estimation should be treated with caution as it is based on aggregate inward FDI flows and not on bilateral inward FDI flows (since suitable data on bilateral inward FDI flows is available only for a few developing countries and years). Further research could be devoted to examining the relevance of these factors at the bilateral and firm levels (that extends beyond the case of an individual country) and also examine the role played by various domestic regulatory and institutional bottlenecks that might attract inward FDI flows.

\section{References}

Agarwal, J.P. (1980) 'Determinants of Foreign Direct Investment: A Survey', Weltwirtschaftliches Archiv, Vol. 116, pp. 739-73, https://doi.org/10.1007/ BF02696547.

Ahmad, Ismail \& Nordin (2015) 'The Impact of Infrastructure on Foreign Direct Investment in Malaysia', International Journal of Management Excellence. https://doi.org/10.17722/ijme.v5i1.196. 
Akther \& Akter (2016) 'The Determinants of Foreign Direct Investment in Bangladesh', Research Journal of Finance and Accounting. https://doi. org/10.1016/S2212-5671(14)00341-4.

Anwara \& Nguyenb (2011) 'Foreign direct investment and trade: The case of Vietnam', Research in International Business and Finance. https://oi. org/10.1016/j.ribaf.2010.05.004.

Arellano, M. and O. Bover (1995) "Another look at the instrumental variables estimation of error components models", Journal of Econometrics, Vol. 68, pp. 29-51, https://doi.org/10.1016/0304-4076(94)01642-D.

Arellano, M. and S. Bond (1991) "Some tests of specification for panel data: Monte Carlo evidence and an application to employment equations". Review of Economic Studies, Vol. 58, pp. 277-97, https://doi.org/10.2307/2297968.

Asiedu, E. (2002) 'On the determinants of foreign direct investment developing countries: if Africa different?' World Development, Vol. 30 (1), pp. 107-119. https://doi.org/10.1016/S0305-750X(01)00100-0.

Asiedu, E. (2006) "Foreign direct investment in Africa: the role of natural resources, market size, government policy, institutions and political instability" World Econ. 29 (1), pp. 63-77, https://doi.org/10.1111/j.1467-9701.2006.00758.x.

Aziz (2017) 'Institutional quality and FDI inflows in Arab economies', Finance Research Letters, https://doi.org/10.1016/j.frl.2017.10.026

Balassa, B. (1966) 'American Direct Investment in the Common Market', Banco Nazionale del Lavoro Quarterly Review: 121-46, https://oi. org/10.1111/j.1468-5965.1990.tb00366.x.

Bevan \& Estrin (2004) 'The determinants of foreign direct investment into European transition economies", Journal of Comparative Economics 32 (2004) 775-787, https://doi.org/10.1016/j.jce.2004.08.006.

Blonigen (2005) 'A Review of the Empirical Literature on FDI Determinants', Atlantic Economic Journal (2005)33:383-403, https://doi.org/10.1007/s11293005-2868-9.

Blundell, R. and S. Bond (1998) "Initial conditions and moment restrictions in dynamic panel data models". Journal of Econometrics, Vol. 87, pp. 11-143, https://doi.org/10.1016/S0304-4076(98)00009-8.

Buchanan, Le \& Rishi (2012) 'Foreign direct investment and institutional quality: Some empirical evidence', International Review of Financial Analysis. https:// doi.org/10.1016/j.irfa.2011.10.001.

Campos \& Kinoshita (2003) 'Why Does FDI Go Where it Goes? New Evidence from the Transition Economies', IMF Working Paper WP/03/228. https://doi. org/10.5089/9781451875461.001.

Castiglione, Gorbunova, Infante \& Smirnova (2012) 'FDI determinants in an idiosyncratic country. A reappraisal over the Russian regions during transition 
years', Communist and Post-Communist Studies. https://doi.org/10.1016/j. postcomstud.2012.02.006.

Caves, R.E. (1974) Economic Analysis and Multinational Enterprise. George Allen and Unwin, London. https://doi.org/10.1111/1467-8268.12039.

Chenga, \& Kwan (2000) 'What are the determinants of the location of foreign direct investment? The Chinese experience', Journal of International Economics, 51(2000), pp. 379-400, https://doi.org/10.1016/S0022-1996(99)00032-X.

Culem, C.G. (1988) 'The Locational Determinants of Direct Investments Among Industrialised Countries', European Economic Review, Vol. 32, pp. 885-904, https://doi.org/10.1016/0014-2921(88)90051-7.

Cuyvers, Soeng, Plasmans \& Bulcke (2011) 'Determinants of foreign direct investment in Cambodia', Journal of Asian Economics. https://doi.org/10.1016/ j.asieco.2011.02.002.

Dellis, Sondermann \& Vansteenkiste (2017) 'Determinants of FDI inflows in advanced economies:'is:Does the quality of economic structures matter?', $E C B$ Working Paper Series. https://doi.org/10.1108/IJoEM-10-2014-0169.

Demirhan \& Masca (2008) 'Determinants of Foreign Direct Investment Flows to Developing Countries: A Cross-Sectional Analysis', Prague Economic Papers, 4, 2008. https://doi.org/10.18267/j.pep.337.

Donnelly (2014) 'A Review of Literature Regarding the Determinants of Foreign Direct Investment (FDI)' Northern Ireland Assembly, Research and Information Service Briefing Paper. https://doi.org/10.1016/j.mulfin.2005.07.002.

Dunning \& Lundan (2008) 'Multinational Enterprises and the Global Economy', Edward Elgar Publishing Limited, Cheltenham. https://doi.org/10.1016/S22125671(14)00341-4.

Dunning, J.H. (1974) The Distinctive Nature of Multinational Enterprise. George Allen and Unwin, London. https://doi.org/10.1016/j.mulfin.2005.07.002.

Dunning, J.H. (1977) "Trade location of economic activity and the MNE: A search of an eclectic approach", in B. Ohlin, P.O. Hesselborn and P.J. Wijkman (eds.), The International Allocation of Economic Activity. Macmillan, London. https:// doi.org/10.1007/978-1-349-03196-2_38.

Dunning, J.H. (1979) "Explaining changing patterns of international production: In defense of the eclectic theory", Oxford Bulletin of Economics and Statistics, vol. 41, No. 4. https://doi.org/10.1111/j.1468-0084.1979.mp41004003.x.

Dunning, J.H. (1988) "The eclectic paradigm of international production: A restatement and some possible extensions", Journal of International Business Studies, Vol. 19, No. 1. https://doi.org/10.1057/palgrave.jibs.8490372.

Edwards (1991) 'Foreign Direct Investment in the United States and U.S. Interests', American Association for the Advancement of Science. https://doi. $\operatorname{org} / 10.1016 /$ j.mulfin.2005.07.002. 
Feenstra (1998) 'Integration of Trade and Disintegration of Production in the Global Economy', Journal of Economic Perspectives Vol. 12 No. 4 Fall 1998. https://doi.org/10.1257/jep.12.4.31.

Graham, E.M. and P. Krugman (1989) Foreign Direct Investment in USA. Institute for International Economics, Washington D.C. https://doi.org/10.1057/ 9781403907493.

Hale \& Xu (2016) 'FDI effects on the labour market of host countries', Federal Reserve Bank of San Francisco. Working Paper 2016-25, https://doi.org/ 10.24148/wp2016-25.

Holland, D. \& Pain, N. (1998) 'The diffusion of innovations in central and eastern Europe: a study of the determinants and impact of foreign direct investment', NIESR Discussion Paper No. 137, National Institute of Social and Economic Research, London. https://doi.org/10.5089/9781451875461.001.

Hunady \& Ovriska (2014) 'Determinants of FDI in EU countries- Do Corporate Taxes Really Matter?', Procedia Economics and Finance. https://doi. org/10.1016/S2212-5671(14)00341-4.

Hymer, S.H. (1976) The International Operation of National Firms: A Study of Direct Foreign Investment. MIT Press, Cambridge, MA, United States. https:// doi.org/10.18267/j.pep.337.

Inekwe (2014) "FDI, Employment and Economic Growth in Nigeria", African Development Review. https://doi.org/10.1111/1467-8268.12039.

Iršová \& Havránek (2013) 'Determinants of Horizontal Spillovers from FDI: Evidence from a Large Meta-Analysis', World Development. https://doi. org/10.1016/j.worlddev.2012.07.001.

Kaliappana, Khamis \& Ismail (2015) 'Determinants of Services FDI Inflows in ASEAN Countries', International Journal of Economics and Management. https://doi.org/10.1016/S2212-5671(14)00341-4.

Kemp, M.C. (1964) The Theory of International Trade. Prentice Hall, London. https://doi.org/10.1016/j.worlddev.1098.12.891.

Kimura \& Lee (1998) 'Korean direct investment in manufacturing: and determinants - an empirical analysis' Journal of International Management 4:2 (1998), pp. 109-127, https://doi.org/10.1016/S1075-4253(98)00010-6.

Kinda (2010) 'Investment Climate and FDI in Developing Countries: Firm-Level Evidence', World Development Vol. 38, No. 4, pp. 498-513, https://doi. org/10.1016/j.worlddev.2009.12.001.

Kindleberger, C.P. (1969) American Business Abroad. Yale University Press, New Haven, CT, United States. https://doi.org/10.1002/tie.5060110207.

Knickerbocker, F.T. (1973) "Oligopolistic reaction and multinational enterprise", Division of Research, Harvard University, Cambridge, MA, United States. https://doi.org/10.1016/0305-750X(85)90002-6. 
Krkoska (2001) 'Foreign direct investment financing of capital formation in Central and Eastern Europe', European Bank of Reconstruction and Development Working Paper No. 67. https://doi.org/10.1016/S0305-750X(01)00100-0.

Kumari \& Sharma (2017) 'Determinants of foreign direct investment in developing countries: a panel data study', International Journal of Emerging Markets. https://doi.org/10.1108/IJoEM-10-2014-0169.

Lemafalussy, A. (1961) Investment and Growth in Mature Economies. Basil Blackwell and Mott, Oxford, United Kingdom. https://doi.org/10.1111/j. 1475-4932.1960.tb00491.x.

Lenuta Carp (2012) "The Impact of FDI on the labor market in Central and Eastern Europe during the international crisis," Review of Applied Socio-Economic Research, Pro Global Science Association, vol. 3(1), pp. 43-54, https://doi. org/10.1016/j.worlddev.2012.12.001.

Lipsey (2000) 'Interpreting developed countries' foreign direct investment', NBER Working paper No. 7810. https://doi.org/10.3386/w7810.

Liu, Daly \& Varua (2013) 'Determinants of China's Regional FDI Inflows', ChinaUSA Business Review. https://doi.org/10.1016/j.worlddev.2009.12.001.

Lizondo, J.S. (1991) 'Foreign Direct Investment', in 'International Monetary Fund, Determinant and Systematic Consequences of International Capita Flows', IMF Occasional Papers No.77 (Washington DC): 68-82. https://doi.org/10.1016/j. econmod.2014.08.017.

MacDougall, G.D.A. (1958) "The benefits and cost of private foreign investment abroad: A theoretical approach", Economic Record, vol. 36. https://doi. org/10.1111/j.1475-4932.1960.tb00491.x.

Moosa \& Cardak (2006) 'The determinants of foreign direct investment: An extreme bounds analysis', Journal of Multinational Financial Management. https://doi.org/10.1016/j.mulfin.2005.07.002.

Moosa, I (2002) Foreign Direct Investment: Theory, Evidence and Practice, Palgrave Macmillan. https://doi.org/10.1057/9781403907493

Paul \& Singh (2017) 'The 45 years of foreign direct investment research: Approaches, advances and analytical areas', The World Economy. https://doi. org/10.1111/twec. 12502 .

Riedel, J. (1975) 'The Nature and Determinants of Export-oriented Foreign Direct Investment in a Developing Country: A Case Study of Taiwan', Weltwirtschaftliches Archiv, vol.3: 505-28, https://doi.org/10.1007/BF02696445.

Robock, S.H. and K. Simmonds (1983) International Business and Multinational Enterprises, Richard D. Irwin, Illinois, United States. https://doi.org/10.1016/j. econmod.2014.08.017.

Saunders, R. (1983) 'The determinants of Interindustry of Variation of Foreign Ownership in Canadian Manufacturing', Canadian Journal of Economics, vol. 15: 77-84, https://doi.org/10.2307/134670. 
Schneider, F and Frey, B.S. (1985) 'Economic and Political Determinants of FDI', World Development, Vol. 13, pp. 161-75, https://doi.org/10.1016/0305750X(85)90002-6.

Shan, Lin, Li \& Zeng (2017) 'Attracting Chinese FDI in Africa, The role of natural resources, market size and institutional quality', Emerald Insight. https://doi. org/10.1016/j.postcomstud.2013.03.006.

Stack, Ravishankar \& Pentecost (2017) 'Foreign direct investment in the eastern European countries: Determinants and performance', Structural Change and Economic Dynamics. https://doi.org/10.1016/j.strueco.2017.04.005.

Sun, Tong \& Yu (2002) 'Determinants of foreign direct investment across China', Journal of International Money and Finance 21 (2002) 79-113. https://doi. org/10.1016/S0261-5606(01)00032-8.

Tang, Yip, \& Ozturk (2014) 'The determinants of foreign direct investment in Malaysia: A case for electrical and electronic industry', Economic Modelling 43:287-292, https://doi.org/10.1016/j.econmod.2014.08.017.

Teixeira, Forte, \& Assunção (2017) 'Do countries' endowments of non-renewable energy resources matter for FDI attraction? A panel data analysis of 125 countries over the period 1995-2012', International Economics. https://doi. org/10.1016/j.inteco.2016.12.002.

Tintin (2013) 'The determinants of foreign direct investment inflows in the Central and Eastern European Countries: The importance of institutions', Communist and Post-Communist Studies UNCTAD, www.unctad.com. https://doi.org/ 10.1016/j.postcomstud.2013.03.006.

UNCTAD, http:/unctadstat.unctad.org/EN/

Vaitsos C.V. (1976) Intercountry Income Distribution and Transnational Enterprises. Clarendon Press, Oxford. https://doi.org/10.1016/j.econmod.2014.08.097.

Vijayakumar, Sridharan \& Rao (2010) 'Determinants of FDI in BRICS Countries: A panel analysis', Int. Journal of Business Science and Applied Management. https://doi.org/10.1016/j.postcomstud.2013.03.006.

Wang, Z.G. and Swain, N.J. (1995) The Determinants of Foreign Direct Investment in Transforming Economies: Empirical Evidence from Hungary and China. Weltwirtschaft liches Archiv, 131, pp. 359-382, https://doi.org/10.1007/ BF02707440.

World Bank, www.worldbank.com

Xaypanya, P., Rangkakulnuwat, P., Paweenawat, S.W. (2015) The determinants of foreign direct investment in ASEAN. The first differencing panel data analysis. Int. J. Soc. Econ. 42 (3), 239-250, https://doi.org/10.1108/IJSE-10-2013-0238. 


\title{
Odrednice izravnih stranih ulaganja: Usporedba različitih skupina zemalja
}

\author{
Minakshee Das ${ }^{1,2}$
}

\begin{abstract}
Sažetak
U ovom radu analiziraju se čimbenici koji određuju izravna strana ulaganja, posebice uloga prirodnih resursa, te gospodarskih i političkih karakteristika zemlje domaćina. Istraživanje se proširuje na postojeću literaturu usredotočujući se na četiri široke skupine zemalja: napredne, tržišta u nastajanju, zemlje u razvoju i tranzicijska gospodarstva, a panel podataka za razdoblje od 1996. do 2016. godine uključuje više od 100 zemalja. U radu se također istražuje scenarij tijekom velikih ekonomskih kriza - azijske krize, Dotcom Bubble, globalne financijske krize $i$ krize državnog duga. Rezultati pokazuju da se s vremenom odrednice ulaznih izravnih stranih ulaganja mijenjaju i da obrasci nisu ujednačeni u četiri skupine zemalja. Nadalje, u radu se uspoređuju odrednice dviju glavnih skupine zemalja, a to su: tržište u nastajanju i zemlje u razvoju provođenjem Chow testa uz jednake koeficijente. Vidljivo je da gospodarski rast $i$ veličina tržišta imaju snažniji pozitivni utjecaj na priljev izravnih stranih ulaganja na tržišta u nastajanju nego na gospodarstva u razvoju. Također, gospodarstva s tržištima u nastajanju su tijekom globalne financijske krize doživjela manji priljev izravnih stranih ulaganja u usporedbi sospodarstvima u razvoju. Ovi rezultati imaju važne implikacije za donositelje politika jer mogu pomoći u prepoznavanju regionalnih čimbenika koji privlače priljev kapitala.
\end{abstract}

Ključne riječi: izravna strana ulaganja, multinacionalne kompanije, odrednice, panel podaci

JEL klasifikacija: F21, F23, O57

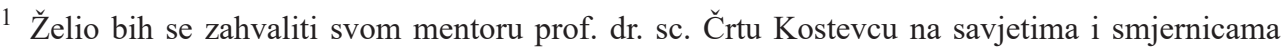
tijekom mog istraživačkog rada i dr. sc. Biswajitu Banerjeeu na njegovim inspirativnim komentarima i sugestijama.

2 Doktorand, School of Economics and Business, University of Ljubljana, Slovenija. Znanstveni interes: međunarodna ekonomija i ekonomija razvoja. Tel.: +91 9954703143. E-mail: gargiminakshee22@gmail.com; md1653@student.uni-lj.si. 


\section{Appendices}

Table 2: Summary of results of selected empirical studies

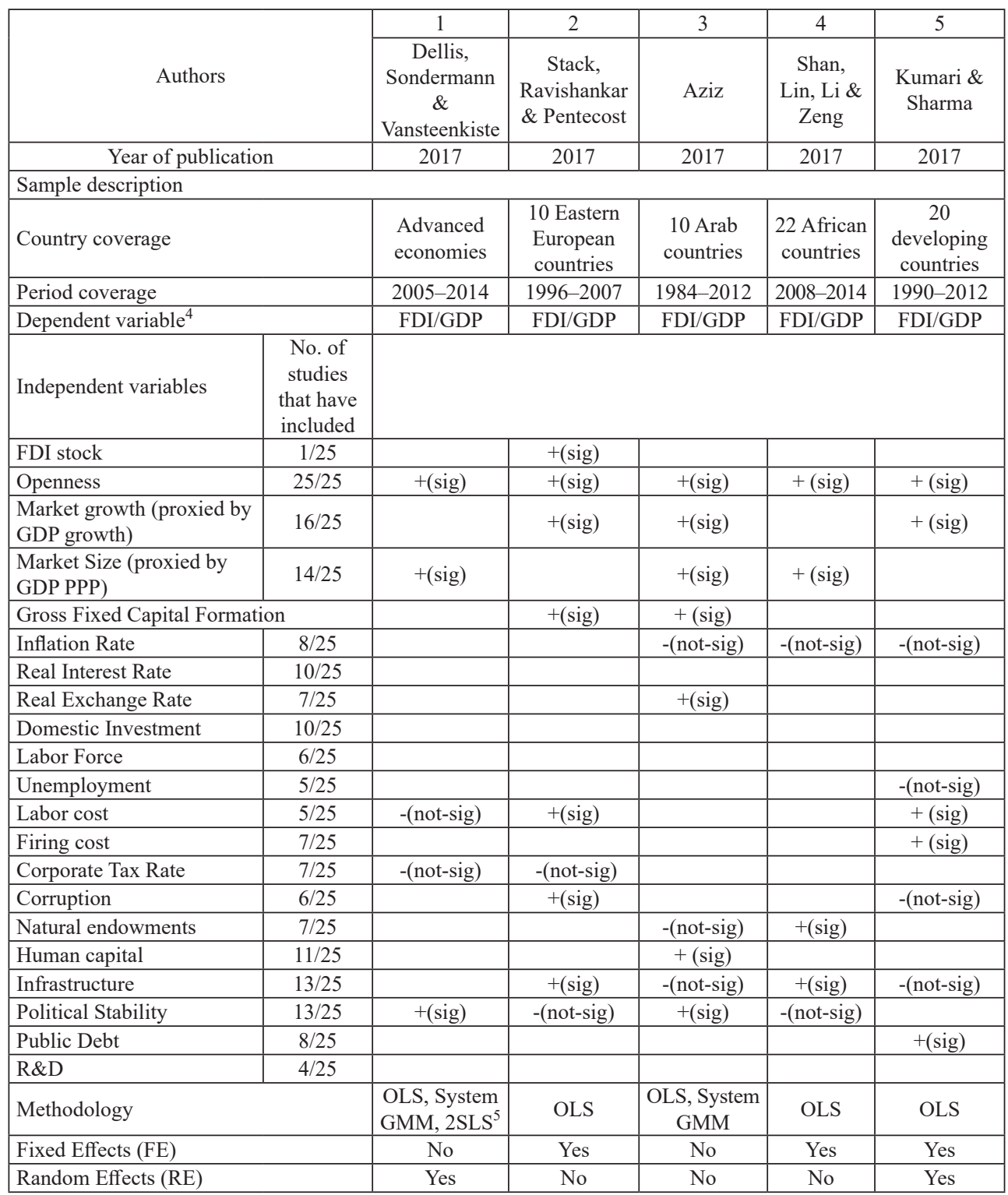

Note: The '+ (sig)' means the coefficient is positive and significant at the $10 \%$ level; The '-(not-sig)' means the coefficient is negative and not statistically significant

4 All dependent variables (FDI/GDP) in Table 2 are in flows and not in stock

5 2SLS is two-stage least square 
Minakshee Das $\bullet$ Determinants of inward foreign direct investment...

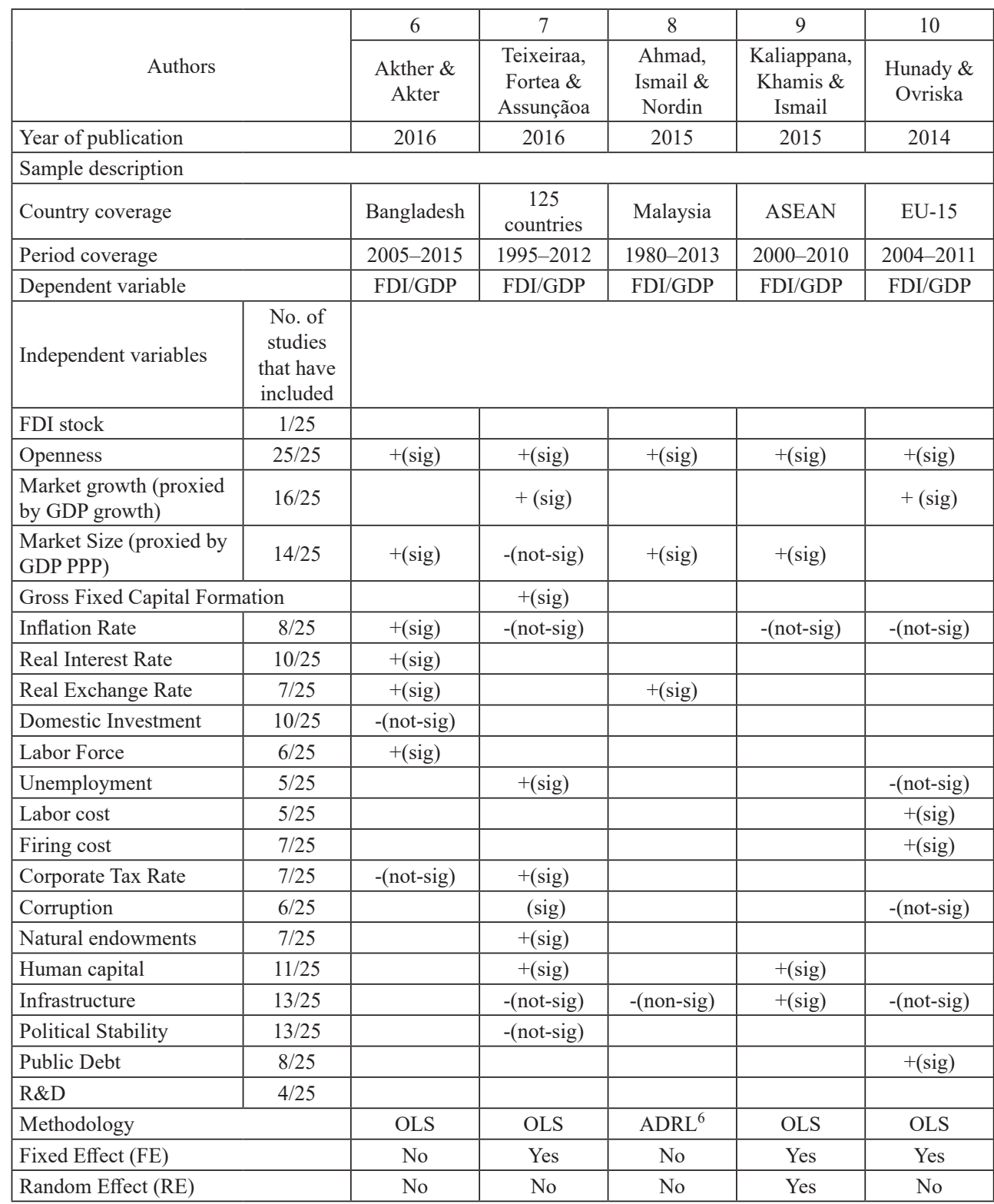

Note: The '+ (sig)' means the coefficient is positive and significant at the $10 \%$ level; The '-(not-sig)' means the coefficient is negative and not statistically significant

\footnotetext{
$\overline{6 \text { ADRL is autoregressive distributed lag }}$
} 
Minakshee Das $\bullet$ Determinants of inward foreign direct investment... Zb. rad. Ekon. fak. Rij. • $2020 \cdot$ vol. $38 \cdot$ no. $1 \cdot 237-269$

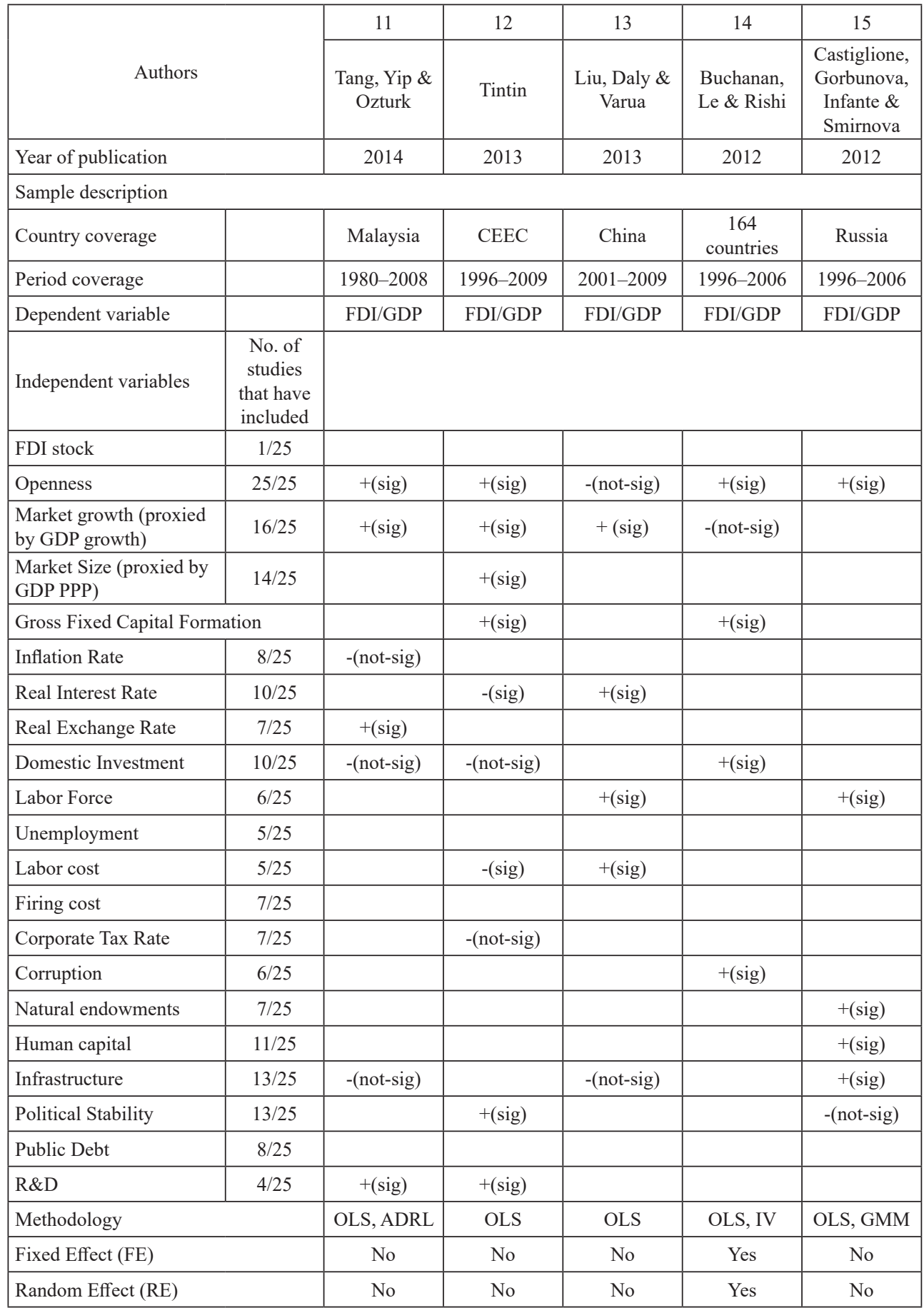

Note: The ' $+($ sig)' means the coefficient is positive and significant at the $10 \%$ level; The '-(not-sig)' means the coefficient is negative and not statistically significant 
Minakshee Das $\bullet$ Determinants of inward foreign direct investment...

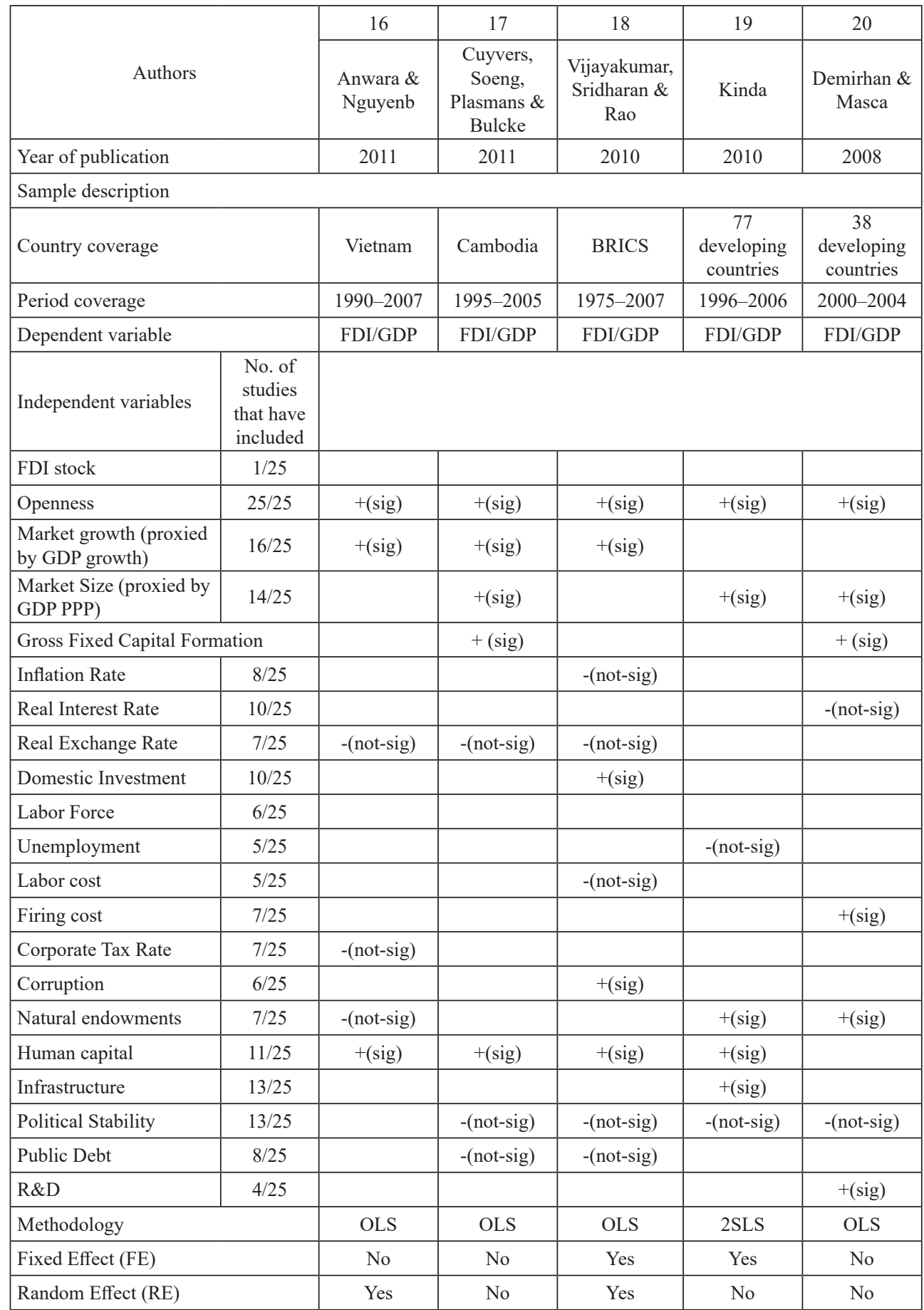

Note: The ' $+($ sig)' means the coefficient is positive and significant at the $10 \%$ level; The '-(not-sig)' means the coefficient is negative and not statistically significant 
Minakshee Das $\bullet$ Determinants of inward foreign direct investment... Zb. rad. Ekon. fak. Rij. $2020 \cdot$ vol. $38 \cdot$ no. $1 \cdot 237-269$

\begin{tabular}{|c|c|c|c|c|c|c|}
\hline \multirow{2}{*}{\multicolumn{2}{|c|}{ Authors }} & 21 & 22 & 23 & 24 & 25 \\
\hline & & $\begin{array}{c}\text { Moosa \& } \\
\text { Cardak }\end{array}$ & $\begin{array}{l}\text { Bevan \& } \\
\text { Estrin }\end{array}$ & $\begin{array}{l}\text { Sun, Tong } \\
\& \text { Yu }\end{array}$ & $\begin{array}{c}\text { Chenga, \& } \\
\text { Kwan }\end{array}$ & $\begin{array}{c}\text { Kimura \& } \\
\text { Lee }\end{array}$ \\
\hline \multicolumn{2}{|c|}{ Year of publication } & 2006 & 2004 & 2002 & 2000 & 1998 \\
\hline \multicolumn{7}{|l|}{ Sample description } \\
\hline \multicolumn{2}{|l|}{ Country coverage } & $\begin{array}{c}138 \\
\text { countries }\end{array}$ & EU & China & China & Korea \\
\hline \multicolumn{2}{|l|}{ Period coverage } & 1994-2005 & $1991-2001$ & 1986-1998 & 1985-1995 & $1981-1995$ \\
\hline \multicolumn{2}{|l|}{ Dependent variable } & FDI/GDP & FDI/GDP & FDI/GDP & FDI/GDP & FDI/GDP \\
\hline Independent variables & $\begin{array}{l}\text { No. of } \\
\text { studies } \\
\text { that have } \\
\text { included }\end{array}$ & & & & & \\
\hline FDI stock & $1 / 25$ & & & & & \\
\hline Openness & $25 / 25$ & $+(\operatorname{sig})$ & $+(\operatorname{sig})$ & $+(\operatorname{sig})$ & $+(\operatorname{sig})$ & $+(\operatorname{sig})$ \\
\hline $\begin{array}{l}\text { Market growth (proxied } \\
\text { by GDP growth) }\end{array}$ & $16 / 25$ & & -(not-sig) & $+(\operatorname{sig})$ & $+(\operatorname{sig})$ & $+(\operatorname{sig})$ \\
\hline $\begin{array}{l}\text { Market Size (proxied by } \\
\text { GDP PPP) }\end{array}$ & $14 / 25$ & -(not-sig) & $+(\operatorname{sig})$ & & & $+(\operatorname{sig})$ \\
\hline \multicolumn{2}{|c|}{ Gross Fixed Capital Formation } & & & $+(\operatorname{sig})$ & & \\
\hline Inflation Rate & $8 / 25$ & $+($ sig $)$ & & & & \\
\hline Real Interest Rate & $10 / 25$ & & $+($ sig $)$ & -(not-sig) & $+(\operatorname{sig})$ & \\
\hline Real Exchange Rate & $7 / 25$ & & $+($ sig $)$ & & -(not-sig) & -(not-sig) \\
\hline Domestic Investment & $10 / 25$ & & & -(not-sig) & & \\
\hline Labor Force & $6 / 25$ & $+($ sig $)$ & & $+($ sig $)$ & & \\
\hline Unemployment & $5 / 25$ & & & & -(not-sig) & \\
\hline Labor cost & $5 / 25$ & & & & & \\
\hline Firing cost & $7 / 25$ & & & & & \\
\hline Corporate Tax Rate & $7 / 25$ & -(not-sig) & & & & \\
\hline Corruption & $6 / 25$ & & & & & \\
\hline Natural endowments & $7 / 25$ & & & & & \\
\hline Human capital & $11 / 25$ & $+(\operatorname{sig})$ & & $+(\operatorname{sig})$ & $+(\operatorname{sig})$ & \\
\hline Infrastructure & $13 / 25$ & & $+(\operatorname{sig})$ & & & \\
\hline Political Stability & $13 / 25$ & & & $+(\operatorname{sig})$ & & -(not-sig) \\
\hline Public Debt & $8 / 25$ & -(not-sig) & -(not-sig) & -(not-sig) & & -(not-sig) \\
\hline R\&D & $4 / 25$ & & & & & $+($ sig $)$ \\
\hline \multicolumn{2}{|l|}{ Methodology } & $\begin{array}{l}\text { Extreme } \\
\text { Bound } \\
\text { Analysis }\end{array}$ & OLS & OLS, GLS & OLS, GMM & Tobit \\
\hline \multicolumn{2}{|l|}{ Fixed Effect (FE) } & No & No & Yes & No & No \\
\hline \multicolumn{2}{|l|}{ Random effect (RE) } & No & Yes & No & No & No \\
\hline
\end{tabular}

Note: The ' $+(\mathrm{sig})$ ' means the coefficient is positive and significant at the $10 \%$ level; The '-(not-sig)' means the coefficient is negative and not statistically significant

Source: Authors' compilation 
Minakshee Das $\bullet$ Determinants of inward foreign direct investment...

\section{A. Description of the dataset}

Table A1: Descriptive statistics

\begin{tabular}{|c|r|r|r|r|c|}
\hline Variable & Observations & \multicolumn{1}{c|}{ Mean } & Std. Dev. & Min & Max \\
\hline IFDI & 8,711 & 3.385762 & 11.97421 & -82.8921 & 466.5622 \\
\hline OPEN & 13,200 & 53.45661 & 53.11015 & 0 & 531.7374 \\
\hline GDPG $_{(\mathrm{t}-1)}$ & 10,063 & 2.086261 & 5.782488 & -64.99726 & 141.6418 \\
\hline GDPP $^{\text {REER }}(\mathrm{t}-1)$ & 5,978 & $2.73 \mathrm{e}^{12}$ & $8.56 \mathrm{e}^{12}$ & $2.13 \mathrm{e}^{10}$ & $1.08 \mathrm{e}^{14}$ \\
\hline GFCF & 5,221 & 2465.133 & 1503.353 & 1 & 5038 \\
\hline ORES & 8,612 & 22.581 & 9.040297 & -2.424358 & 219.0694 \\
\hline INFRA & 7,507 & 7.847904 & 14.16915 & 0 & 99.0677 \\
\hline GOV & 10,128 & 15.44875 & 18.32691 & 0 & 132.9533 \\
\hline
\end{tabular}

Table A2: Correlation matrix

\begin{tabular}{|c|c|c|c|c|c|c|c|c|c|}
\hline & IFDI & OPEN & $\mathrm{GDPG}_{(\mathrm{t}-1)}$ & GDPP & $\operatorname{REER}_{(\mathrm{t}-1)}$ & GFCF & INFRA & ORES & GOV \\
\hline \multirow[t]{2}{*}{ IFDI } & 1.000 & & & & & & & & \\
\hline & (8711) & & & & & & & & \\
\hline \multirow[t]{3}{*}{ OPEN } & $0.2714^{*}$ & 1.000 & & & & & & & \\
\hline & 0.000 & & & & & & & & \\
\hline & (8711) & (13200) & & & & & & & \\
\hline \multirow[t]{3}{*}{$\mathrm{GDPG}_{(\mathrm{t}-1)}$} & $0.0940^{*}$ & $0.0982 *$ & 1.000 & & & & & & \\
\hline & 0.000 & 0.000 & & & & & & & \\
\hline & (8353) & (10063) & (10063) & & & & & & \\
\hline \multirow[t]{3}{*}{ GDPP } & $-0.0462 *$ & $-0.1493 *$ & 0.0237 & 1.000 & & & & & \\
\hline & 0.0005 & 0.000 & 0.0696 & & & & & & \\
\hline & $(5723)$ & (5978) & $(5888)$ & (5978) & & & & & \\
\hline \multirow[t]{3}{*}{$\operatorname{REER}_{(\mathrm{t}-1)}$} & 0.0141 & $0.0328 *$ & $0.0412 *$ & $-0.0336^{*}$ & 1.000 & & & & \\
\hline & 0.3269 & 0.0177 & 0.0033 & 0.0254 & & & & & \\
\hline & (4866) & (5221) & (5100) & (4423) & (5221) & & & & \\
\hline \multirow[t]{3}{*}{ GFCF } & $0.1815^{*}$ & $0.3071 *$ & $0.3048 *$ & $0.0769 *$ & 0.0003 & 1.000 & & & \\
\hline & 0.000 & 0.000 & 0.000 & 0.000 & 0.9858 & & & & \\
\hline & (7630) & (8612) & (8332) & (5428) & (4572) & (8612) & & & \\
\hline \multirow[t]{3}{*}{ INFRA } & $0.1243 *$ & $0.1059 *$ & $0.0272 *$ & $0.1304 *$ & 0.0056 & $0.0581 *$ & 1.000 & & \\
\hline & 0.000 & 0.000 & 0.0111 & 0.000 & 0.6911 & 0.000 & & & \\
\hline & $(8169)$ & $(10128)$ & $(8694)$ & $(5901)$ & (4986) & (7779) & $(10128)$ & & \\
\hline \multirow[t]{3}{*}{ ORES } & 0.0077 & $-0.0364 *$ & $-0.0507^{*}$ & $-0.0831 *$ & 0.0061 & $-0.0643 *$ & $-0.1645^{*}$ & 1.000 & \\
\hline & 0.5376 & 0.0016 & 0.000 & 0.000 & 0.7073 & 0.000 & 0.000 & & \\
\hline & (6447) & (7507) & (6948) & (4497) & (3815) & (6465) & (6515) & $(7507)$ & \\
\hline \multirow[t]{3}{*}{ GOV } & 0.0014 & -0.0152 & 0.0145 & 0.0013 & -0.0147 & $0.0646^{*}$ & 0.0133 & -0.0132 & 1.000 \\
\hline & 0.9343 & 0.3432 & 0.3738 & 0.9386 & 0.3791 & 0.0002 & 0.4093 & 0.4718 & \\
\hline & (3666) & (3914) & (3762) & (3721) & (3584) & (3410) & (3859) & (2984) & (3914) \\
\hline
\end{tabular}

Figures in parentheses are number of observation.; * are significant at $\mathrm{p}<0.05$ 
Table A3: List of country groupings

\begin{tabular}{|c|c|c|}
\hline \multicolumn{3}{|l|}{ Advanced economies } \\
\hline 1. America & \multicolumn{2}{|c|}{ Canada, United States } \\
\hline 2. Asia & \multicolumn{2}{|l|}{ Israel, Japan } \\
\hline 3. Europe & \multicolumn{2}{|c|}{$\begin{array}{l}\text { Austria, Belgium, Cyprus, Denmark, Estonia, Finland, France, Germany, } \\
\text { Greece, Iceland, Ireland, Italy, Latvia, Lithuania, Luxembourg, Malta, } \\
\text { Netherlands, Norway, Portugal, Slovakia, Slovenia, Spain, Sweden, } \\
\text { Switzerland, United Kingdom }\end{array}$} \\
\hline 4. Oceania & \multicolumn{2}{|c|}{ Australia, New Zealand } \\
\hline \multicolumn{3}{|c|}{ Emerging-market economies } \\
\hline 1. Africa & \multicolumn{2}{|c|}{ Egypt, Nigeria \& South Africa } \\
\hline 2. America & \multicolumn{2}{|c|}{$\begin{array}{l}\text { Argentina, Brazil, Chile, Colombia, Ecuador, Mexico, Peru, Uruguay, } \\
\text { Venezuela }\end{array}$} \\
\hline 3. Asia & \multicolumn{2}{|c|}{ China, Korea, India, Indonesia, Malaysia, Philippines, Singapore, Thailand } \\
\hline 4. Middle-East & \multicolumn{2}{|c|}{ Bahrain, Kuwait, Oman, Qatar, Saudi Arabia, Turkey, United Arab Emirates } \\
\hline 5. Europe & \multicolumn{2}{|c|}{$\begin{array}{l}\text { Bulgaria, Croatia, Czech Republic, Hungary, Poland, Romania, Russian } \\
\text { Federation }\end{array}$} \\
\hline \multicolumn{3}{|c|}{ Developing economies } \\
\hline \multirow[t]{5}{*}{ 1. Africa } & Eastern Africa & $\begin{array}{l}\text { Burundi, Djibouti, Ethiopia, Kenya, Madagascar, Malawi, } \\
\text { Mauritius, Mozambique, Rwanda, Somalia, Uganda, } \\
\text { United Republic of, Tanzania, Zambia, Zimbabwe }\end{array}$ \\
\hline & Middle Africa & $\begin{array}{l}\text { Angola, Cameroon, Central African Republic, Chad, } \\
\text { Congo, Dem. Rep. of the Congo, Gabon }\end{array}$ \\
\hline & Northern Africa & Algeria, Libya, Morocco, Sudan, Tunisia \\
\hline & South Africa & Botswana, Lesotho, Namibia \\
\hline & Western Africa & $\begin{array}{l}\text { Benin, Burkina Faso, Cabo Verde, Côte d'Ivoire, } \\
\text { Gambia, Ghana, Guinea, Guinea-Bissau, Liberia, Mali, } \\
\text { Mauritania, Senegal, Sierra Leone \& Togo }\end{array}$ \\
\hline \multirow[t]{2}{*}{ 2. America } & Caribbean & $\begin{array}{l}\text { Antigua and Barbuda, Barbados, Cuba, Dominica, } \\
\text { Dominican Republic, Grenada, Haiti, Jamaica, } \\
\text { Trinidad and Tobago }\end{array}$ \\
\hline & Central America & $\begin{array}{l}\text { Belize, Costa Rica, El Salvador, Guatemala, Honduras, } \\
\text { Nicaragua }\end{array}$ \\
\hline \multirow[t]{4}{*}{ 3. Asia } & Eastern & Mongolia \\
\hline & Southern & $\begin{array}{l}\text { Afghanistan, Bangladesh, Bhutan, Iran (Islamic } \\
\text { Republic of), Maldives, Nepal, Pakistan, Sri Lanka }\end{array}$ \\
\hline & South-Eastern & $\begin{array}{l}\text { Cambodia, Lao People's Dem. Rep., Myanmar, Viet } \\
\text { Nam }\end{array}$ \\
\hline & Western Asia & Iraq, Jordan, Lebanon, Yemen \\
\hline 4. Oceania & \multicolumn{2}{|c|}{$\begin{array}{l}\text { Fiji, Guam, Kiribati, Papua New Guinea, Samoa, Solomon Islands, Tonga, } \\
\text { Tuvalu, }\end{array}$} \\
\hline Transition economies & \multicolumn{2}{|c|}{$\begin{array}{l}\text { Albania, Armenia, Azerbaijan, Bosnia \& Herzegovina, Georgia, Kazakhstan, } \\
\text { Kyrgyzstan, Montenegro, Moldova, Serbia, Tajikistan, Macedonia, } \\
\text { Turkmenistan, Ukraine, Uzbekistan }\end{array}$} \\
\hline
\end{tabular}

Sample include developed countries, emerging-market economies, developing countries and transition economies. Groupings follow the classification by UNCTAD. However, countries classified as emerging-market economies have been removed from developing country group if they also appear there. 
Minakshee Das $\bullet$ Determinants of inward foreign direct investment...

B. Additional empirical results

Table B1: Determinants of inward FDI- full sample Dependent variable: IFDI (the ratio of IFDI flow to GDP)

\begin{tabular}{|c|c|c|}
\hline & FE & System GMM \\
\hline \multirow{2}{*}{ IFDI $_{(t-1)}$} & & $0.440 * *$ \\
\hline & & $(0.188)$ \\
\hline \multirow{2}{*}{ OPEN } & 0.0397 & $0.132 *$ \\
\hline & $(0.0253)$ & $(0.0697)$ \\
\hline \multirow{2}{*}{$\mathrm{GDPG}_{(\mathrm{t}-1)}$} & -0.0709 & -0.176 \\
\hline & $(0.0836)$ & $(0.129)$ \\
\hline \multirow{2}{*}{ GDPP } & $-1.18 \mathrm{e}^{-10 * * *}$ & $-1.46 \mathrm{e}^{-5 *}$ \\
\hline & $\left(3.09 \mathrm{e}^{-7}\right)$ & $\left(1.48 \mathrm{e}^{-6}\right)$ \\
\hline \multirow{2}{*}{$\operatorname{REER}_{(\mathrm{t}-1)}$} & $-4.70 \mathrm{e}^{-5}$ & -0.000754 \\
\hline & $(0.000238)$ & $(0.00588)$ \\
\hline \multirow{2}{*}{ GFCF } & $0.221 * * *$ & 0.836 \\
\hline & $(0.0686)$ & $(0.815)$ \\
\hline \multirow{2}{*}{ ORES } & 0.00138 & -0.0019 \\
\hline & $(0.0503)$ & $(0.269)$ \\
\hline \multirow[t]{2}{*}{ INFRA } & 0.0449 & 0.00176 \\
\hline & $(0.0325)$ & $(0.276)$ \\
\hline \multirow[t]{2}{*}{ GOV } & 2.636 & 5.853 \\
\hline & $(2.471)$ & $(5.603)$ \\
\hline \multicolumn{3}{|l|}{ Economic crisis } \\
\hline \multirow{2}{*}{$\begin{array}{l}\text { Asian crisis } \\
(1997-1998)\end{array}$} & -0.983 & -0.908 \\
\hline & $(0.745)$ & $(1.605)$ \\
\hline \multirow{2}{*}{$\begin{array}{l}\text { Dotcom Bubble } \\
(2001)\end{array}$} & -0.716 & -1.142 \\
\hline & $(0.607)$ & $(1.712)$ \\
\hline \multirow{2}{*}{$\begin{array}{l}\text { Global Financial crisis } \\
(2007-2008)\end{array}$} & $3.270^{*}$ & 1.286 \\
\hline & $(1.919)$ & $(4.717)$ \\
\hline \multirow{2}{*}{$\begin{array}{l}\text { Sovereign Debt crisis } \\
(2011-2012)\end{array}$} & 1.31 & 2.468 \\
\hline & $(0.803)$ & $(4.73)$ \\
\hline \multirow{2}{*}{ Constant } & -3.489 & -15.2 \\
\hline & $(2.597)$ & $(25.3)$ \\
\hline Observations & 2,669 & 2,658 \\
\hline R-squared & 0.021 & \\
\hline Number of countries & 162 & 162 \\
\hline
\end{tabular}

Figures in parentheses are robust standard errors.; ***,**.* are significant respectively to $\mathrm{p}<0.01, \mathrm{p}<0.05, \mathrm{p}<0.1 ; \mathrm{e}=10$ 
Minakshee Das $\bullet$ Determinants of inward foreign direct investment...

Table B2: Determinants of inward FDI at the time of major economic crises - FE Dependent variable: IFDI (the ratio of IFDI flow to GDP)

\begin{tabular}{|c|c|c|c|c|}
\hline & Advanced & $\begin{array}{c}\text { Emerging- } \\
\text { market }\end{array}$ & Developing & Transition \\
\hline \multirow{2}{*}{ OPEN } & -0.0806 & $0.0234 * *$ & $0.0547 * * *$ & $0.104 *$ \\
\hline & $(0.102)$ & $(0.0109)$ & $(0.0188)$ & (0.0489) \\
\hline \multirow{2}{*}{$\mathrm{GDPG}_{(\mathrm{t}-1)}$} & -0.645 & $0.0644 * *$ & 0.011 & 0.0279 \\
\hline & $(0.658)$ & $(0.027)$ & $(0.0451)$ & $(0.0422)$ \\
\hline \multirow{2}{*}{ GDPP } & $2.36 \mathrm{e}^{-11}$ & $2.36 \mathrm{e}^{-11}$ & $2.36 \mathrm{e}^{-11}$ & $2.36 \mathrm{e}^{-11}$ \\
\hline & $\left(1.86 \mathrm{e}^{-11}\right)$ & $\left(1.86 \mathrm{e}^{-11}\right)$ & $\left(1.86 \mathrm{e}^{-11}\right)$ & $\left(1.86 \mathrm{e}^{-11}\right)$ \\
\hline \multirow{2}{*}{$\operatorname{REER}_{(t-1)}$} & $2.86 \mathrm{e}^{-5}$ & -0.000176 & $-9.10 e^{-5}$ & 0.000151 \\
\hline & $(0.000957)$ & $(0.000157)$ & $\left(8.25 \mathrm{e}^{-5}\right)$ & $(0.000162)$ \\
\hline \multirow{2}{*}{ GFCF } & 0.0417 & 0.0192 & $0.193 * * *$ & $0.548^{*}$ \\
\hline & $(0.363)$ & $(0.0514)$ & $(0.0631)$ & $(0.27)$ \\
\hline \multirow{2}{*}{ ORES } & 0.0741 & 0.0423 & -0.00579 & -0.133 \\
\hline & $(0.0677)$ & $(0.0533)$ & $(0.0549)$ & $(0.129)$ \\
\hline \multirow{2}{*}{ INFRA } & -0.0256 & 0.184 & 0.0288 & -0.0375 \\
\hline & $(0.363)$ & $(0.131)$ & $(0.0219)$ & $(0.0313)$ \\
\hline \multirow{2}{*}{ GOV } & 12.05 & 0.808 & -0.1 & -0.0841 \\
\hline & $(11.73)$ & $(0.526)$ & $(0.445)$ & $(1.255)$ \\
\hline \multicolumn{5}{|l|}{ Economic crisis } \\
\hline \multirow{2}{*}{$\begin{array}{l}\text { Asian crisis } \\
(1997-1998)\end{array}$} & -3.133 & 0.0675 & -0.172 & 1.731 \\
\hline & $(2.325)$ & $(0.405)$ & $(0.348)$ & $(1.073)$ \\
\hline \multirow{2}{*}{$\begin{array}{l}\text { Dotcom Bubble } \\
(2001)\end{array}$} & -1.294 & -0.0169 & -0.463 & 0.668 \\
\hline & $(1.801)$ & $(0.355)$ & $(0.309)$ & (1.312) \\
\hline \multirow{2}{*}{$\begin{array}{l}\text { Global Financial crisis } \\
(2007-2008)\end{array}$} & 11.56 & 2.18 & $1.630 * * *$ & -0.000392 \\
\hline & $(9.065)$ & $(1.463)$ & $(0.43)$ & (1.678) \\
\hline \multirow{2}{*}{$\begin{array}{l}\text { Sovereign Debt crisis } \\
(2011-2012)\end{array}$} & $5.950 *$ & -0.605 & $0.987 *$ & -0.564 \\
\hline & $(3.407)$ & $(0.417)$ & $(0.524)$ & $(0.594)$ \\
\hline \multirow{2}{*}{ Constant } & -3.611 & -0.53 & $-4.933 * *$ & $-14.71^{*}$ \\
\hline & $(13.71)$ & $(2.536)$ & $(2.223)$ & $(7.833)$ \\
\hline Observations & 697 & 648 & 1,234 & 231 \\
\hline R-squared & 0.035 & 0.106 & 0.199 & 0.473 \\
\hline Number of countries & 36 & 35 & 84 & 15 \\
\hline
\end{tabular}

Figures in parentheses are robust standard errors.; ***,**.* are significant respectively to $\mathrm{p}<0.01, \mathrm{p}<0.05, \mathrm{p}<0.1 ; \mathrm{e}=10$ 
Minakshee Das $\bullet$ Determinants of inward foreign direct investment...

Table B3: Determinants of inward FDI at the time of major economic crisesSystem GMM

Dependent variable: IFDI (the ratio of IFDI flow to GDP)

\begin{tabular}{|c|c|c|c|c|}
\hline & Advanced & $\begin{array}{c}\text { Emerging- } \\
\text { market }\end{array}$ & Developing & Transition \\
\hline \multirow{2}{*}{$\operatorname{IFDI}_{(t-1)}$} & $0.499 * * *$ & $0.223 *$ & $-0.174 *$ & $0.523 * * *$ \\
\hline & $(0.182)$ & $(0.121)$ & $(0.102)$ & $(0.0998)$ \\
\hline \multirow{2}{*}{ OPEN } & $0.178 * * *$ & $0.0307 * *$ & $0.140 * * *$ & $0.0595 * *$ \\
\hline & $(0.0582)$ & $(0.0144)$ & $(0.0219)$ & $(0.0227)$ \\
\hline \multirow{2}{*}{$\mathrm{GDPG}_{(\mathrm{t}-1)}$} & -0.66 & 0.13 & $-0.0930^{*}$ & -0.0212 \\
\hline & $(0.867)$ & $(0.101)$ & $(0.0548)$ & $(0.0419)$ \\
\hline \multirow{2}{*}{ GDPP } & $2.36 \mathrm{e}^{-11}$ & $2.36 \mathrm{e}^{-11}$ & $2.36 \mathrm{e}^{-11}$ & $2.36 \mathrm{e}^{-11}$ \\
\hline & $\left(1.86 \mathrm{e}^{-11}\right)$ & $\left(1.86 \mathrm{e}^{-11}\right)$ & $\left(1.86 \mathrm{e}^{-11}\right)$ & $\left(1.86 \mathrm{e}^{-11}\right)$ \\
\hline \multirow{2}{*}{$\operatorname{REER}_{(\mathrm{t}-1)}$} & -0.00193 & 0.000289 & $-2.83 \mathrm{E}-05$ & 0.000337 \\
\hline & $(0.00564)$ & $(0.000448)$ & $(0.000715)$ & $(0.000456)$ \\
\hline \multirow{2}{*}{ GFCF } & 1.808 & -0.214 & $0.440 * *$ & $0.432 *$ \\
\hline & $(1.555)$ & $(0.198)$ & $(0.187)$ & $(0.232)$ \\
\hline \multirow{2}{*}{ ORES } & -0.543 & $0.235^{* *}$ & 0.0408 & 0.028 \\
\hline & $(0.822)$ & $(0.114)$ & $(0.053)$ & $(0.0811)$ \\
\hline \multirow{2}{*}{ INFRA } & 0.233 & 0.0235 & -0.0154 & -0.0646 \\
\hline & $(0.711)$ & $(0.116)$ & $(0.173)$ & $(0.105)$ \\
\hline \multirow{2}{*}{ GOV } & 5.557 & 1.313 & -0.0643 & -0.962 \\
\hline & $(11.71)$ & $(1.215)$ & $(2.387)$ & $(1.275)$ \\
\hline \multicolumn{5}{|l|}{ Economic crisis } \\
\hline \multirow{2}{*}{$\begin{array}{l}\text { Asian crisis } \\
(1997-1998)\end{array}$} & 0.318 & 0.325 & 0.274 & $2.759 * * *$ \\
\hline & $(2.628)$ & $(0.716)$ & (1.136) & $(0.903)$ \\
\hline \multirow{2}{*}{$\begin{array}{l}\text { Dotcom Bubble } \\
(2001)\end{array}$} & -1.334 & -0.262 & -0.127 & 1.441 \\
\hline & $(1.303)$ & $(0.605)$ & $(0.918)$ & $(1.506)$ \\
\hline \multirow{2}{*}{$\begin{array}{l}\text { Global Financial crisis } \\
(2007-2008)\end{array}$} & -2.907 & 2.709 & $1.916^{* * *}$ & -0.384 \\
\hline & $(5.949)$ & $(1.786)$ & $(0.686)$ & $(0.834)$ \\
\hline \multirow{2}{*}{$\begin{array}{l}\text { Sovereign Debt crisis } \\
(2011-2012)\end{array}$} & 4.392 & 0.0635 & 0.616 & -0.7 \\
\hline & $(9.197)$ & $(0.977)$ & $(1.364)$ & $(0.851)$ \\
\hline \multirow{2}{*}{ Constant } & $-54.25 * *$ & 1.988 & $-16.07 * * *$ & $-13.73 * *$ \\
\hline & $(25.2)$ & $(4.283)$ & $(4.874)$ & $(5.494)$ \\
\hline Observations & 694 & 648 & 1,227 & 230 \\
\hline Number of countries & 36 & 35 & 84 & 15 \\
\hline
\end{tabular}

Figures in parentheses are robust standard errors.; ***,**.* are significant respectively to $\mathrm{p}<0.01, \mathrm{p}<0.05, \mathrm{p}<0.1 ; \mathrm{e}=10$ 